\title{
The structure and cryptic layering of the Pados-Tundra ultramafic complex, Serpentinite belt, Kola Peninsula, Russia
}

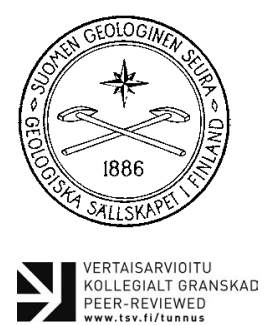

PEER-REVIEWED

\author{
Andrei Y. Barkov ${ }^{*}$, Andrey A. Nikiforov ${ }^{1}$ and Robert F. Martin ${ }^{2}$ \\ ${ }^{1}$ Research Laboratory of Industrial and Ore Mineralogy, Cherepovets State University, \\ 5 Lunacharsky Avenue, 162600 Cherepovets, Russia \\ ${ }^{2}$ Department of Earth and Planetary Sciences, McGill University, 3450 University Street, \\ Montreal, Quebec H3A OE8, Canada
}

\section{Abstract}

The Paleoproterozoic Pados-Tundra ultramafic complex, $\sim 6 \times 1.5-2.1 \mathrm{~km}$ in size and $\sim 2.1 \mathrm{Ga}$ in age, located in the Kola Peninsula of Russia, is the main representative of the Serpentinite belt in the northern Fennoscandian Shield. It is composed of fragmented or foliated bodies of dunite-harzburgite-orthopyroxenite; these have an elevated potential for $\mathrm{Cr}$ and the platinum-group elements (PGE). In general, the complex consists of the Dunite Zone (olivine cumulates) and Orthopyroxenite Zone (orthopyroxene + olivine cumulates, interlayered); its upper zones of more evolved rocks of mafic compositions appear to have been removed by erosion. The complex shows well-recognized patterns of cryptic layering, documented along cross-sections in grains of olivine and Ca-poor pyroxene. Narrow ranges of high-Mg compositions are observed in olivine $\left[\mathrm{Fo}_{85.5-90.6}\right]$ and orthopyroxene $\left[\mathrm{Wo}_{<0.1-3.0} \mathrm{En}_{85.1-91.2} \mathrm{Fs}_{8.1-12.5}\right]$. Their trends of crystallization indicate that cumulate olivine, orthopyroxene, and olivine-orthopyroxene rocks (dunite and orthopyroxenite, with subordinate harzburgite and olivine-bearing orthopyroxenite) become, in general, more evolved toward the internal portions of the complex; stratigraphically lower and early-crystallizing cumulates are exposed closer to its outer contact. The compositions of early phases of cumulus origin, $\mathrm{Fo}_{91}$ olivine and $\mathrm{En}_{91}$, orthopyroxene are notably magnesian, implying an elevated $M g \#$ in the parental magma. The anomalously $\mathrm{Cr}$-Al-rich grains of serpentine (up to $\sim 2.5 \mathrm{wt} . \% \mathrm{Cr}_{2} \mathrm{O}_{3}$ and $\sim 4$. Owt.\% $\mathrm{Al}_{2} \mathrm{O}_{3}$ ), hitherto unreported, are present in specimens of dunite near the northeastern margin of the complex. Supercooling and metastable crystallization likely affected the melt in the eastern portion of the complex near the Dunite block (i.e., host for segregations and stratiform-like layers of chromitite) and relatively close to the outer contact. An uncommon mineralization of the PGE is associated with the chromitite deposits at Pados-Tundra.

Keywords: Pados-Tundra complex, ultramafic rocks, layered intrusions, Serpentinite belt, Kola Peninsula, Russia, Fennoscandian Shield.

* Corresponding author (e-mail: ore-minerals@mail.ru) 


\section{Introduction}

In the Fennoscandian (Baltic) Shield, Paleoproterozoic layered intrusions $(2.4-2.5 \mathrm{Ga}$ in age) are relatively common in northwestern Russia, i.e., in Russian Karelia and in the Kola Peninsula, and in Finland (e.g., Alapieti et al., 1990). In contrast, igneous complexes of mafic-ultramafic compositions of other age groups are comparatively rarer and poorly characterized.

Our aim here is to report new observations and analytical results obtained for the Pados-Tundra complex $(-2.15 \mathrm{Ga})$; it is the major member of the Serpentinite belt or the Notozerskiy (Notozero) suite, which represents a younger group of fragmented bodies (e.g., Chapes-Varaka, KarekaTundra, Lyavaraka, and outcrops of ultramafic rocks mapped in the area of the headwaters of the Terma River) distributed over a wide area in the Kola Peninsula (e.g., Murashov, 1958; Vinogradov, 1971; Zak, 1980; Dokuchaeva, 1981; Mamontov $\&$ Dokuchaeva, 2005). We discuss details of the internal structure of the complex and implications of compositional data obtained on specimens collected along two sampling traverses ( $a-b$ and $c-d$ : Figs. 1, 2a); they indicate the existence of cryptic layering in this complex, which hosts an uncommon mineralization of the platinum-group elements (PGE) associated with chromitite of the Dunite block in the northeastern portion of the complex (Barkov et al., 2017).

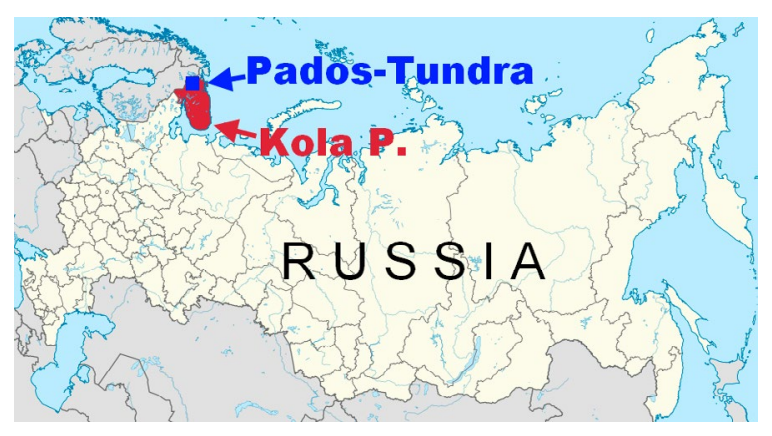

Figure 1. The location of the Pados-Tundra complex in the Russian Federation.

\section{Geological background}

\subsection{The Pados-Tundra complex}

The Pados-Tundra complex (Figs. 1-6), a large body of ultramafic rocks $(-6 \times 1.5-2.1 \mathrm{~km})$ situated close to the Finnish border, has a well-established Paleoproterozoic age, -2.15 Ga (Shapkin et al., 2008; Shapkin \& Bayanova, 2009). It is associated with a Paleoproterozoic upthrust in the Lapland granulite rocks of the Kola-Mezenskiy block, near its contact with the Archean Belomorskiy block of granite and gneiss. This complex consists of minor metagabbroic rocks in the marginal series (or "endocontact zone") and a series of dunite-harzburgite-orthopyroxenite rocks. Three stratiform-like layers of chromitite $\left(\mathrm{Cr}_{2}, \mathrm{Cr}_{3}\right.$, and $\mathrm{Cr}_{4}$ after Mamontov \& Dokuchaeva, 2005) are developed, along with segregations and pipe-like bodies rich in $\mathrm{Cr}-\mathrm{Fe}$ oxide in the Dunite block. Two types of ultramafic rocks, i.e., orthopyroxenite (up to $95-97$ vol.\% orthopyroxene) and dunite (90-95 vol.\% olivine and minor orthopyroxene), strongly dominate the sequence of orthopyroxene-olivine cumulates (e.g., Figs. 7-9). Harzburgite (60-70 vol.\% olivine and up to 40 vol.\% orthopyroxene) is strongly subordinate. Zones enriched in $\mathrm{Cr}-\mathrm{Fe}$ oxide (mostly chromian magnetite) occur near the contact. Five vein-like zones of talc-magnesite, measuring 4 to $76 \mathrm{~m}$ thick and 0.1 to $\sim 1 \mathrm{~km}$ long, have been mapped (Fig. 2a).

\subsection{The Malyi Pados body}

A relatively small body of dominantly ultramafic rocks, Malyi Pados or "Little Pados" (Fig. 2b), has been interpreted as a satellite intrusion (Mamontov \& Dokuchaeva, 2005, and references therein). Instead, we suggest that it represents a large block (composed of subordinate blocks, as indicated in the satellite images; MP: Fig. 6b) separated as a result of detachment from the Pados-Tundra complex. Indeed, the Malyi Pados body exhibits about the same kind of modal variations (Fig. 2b). We note 


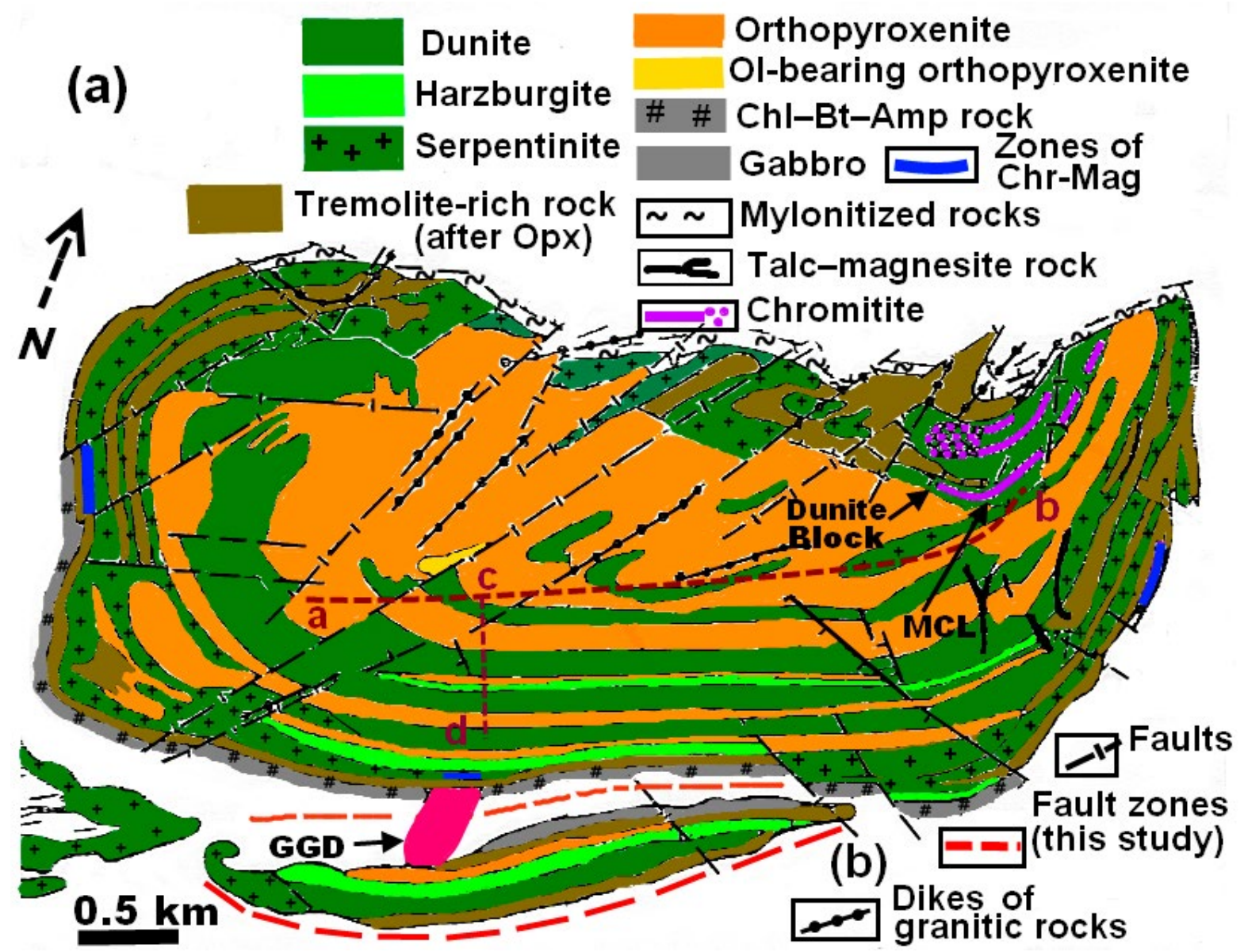

Figure 2. Geological map of the Pados-Tundra complex (a), and of the Malyi-Pados massif (b), slightly modified from Mamontov \& Dokuchaeva (2005). The lines $a-b$ and $c$ - $d$ indicate schematically the sampling traverses used in the present investigation. Stratiform-like layers, segregations and pipe-like orebodies of chromitite are shown schematically in purple; these mineralized zones are hosted by the Dunite block. In addition, zones of chromite-magnetite mineralization (Chr-Mag), present at the outer contact, are shown in blue. MCL is the Main Chromitite Layer (or $\mathrm{Cr}_{2}$ ); and GGD is a granite gneiss dome. The surrounding country rocks are not shown; these are composed of granite gneiss, granodiorite gneiss, and garnet amphibolite of Archean age.

that the "gabbro" noted previously in the upper zone of Malyi Pados may, in fact, represent metagabbro, related to a chlorite-biotite-amphibole rock present in the marginal series of the Pados-Tundra complex. Hypothetically, these two bodies could be joined together, delimited by fault zones, as indicated (Fig. 2b). The Malyi Pados block may have experienced a partial rotation, presumably associated with the upthrust movements generated during episodes of tectogenesis and orogeny. The evolution of the Fennoscandian Shield involves events of the Lapland-Kola orogen (1.94-1.86 Ga; Lehtinen et al., 2005, Daly et al., 2006) and of the Svecofennian orogen (1.92-1.79 Ga; e.g., Lahtinen, 2012). Our interpretation is consistent with a slab-like shape of the Malyi Pados body: it is elongate and fairly thin: $<0.5 \mathrm{~km}$ (Fig. 2b). A rather homogeneous and unlayered rock of a finegrained texture would be expected if there had been a separate injection of magma. 


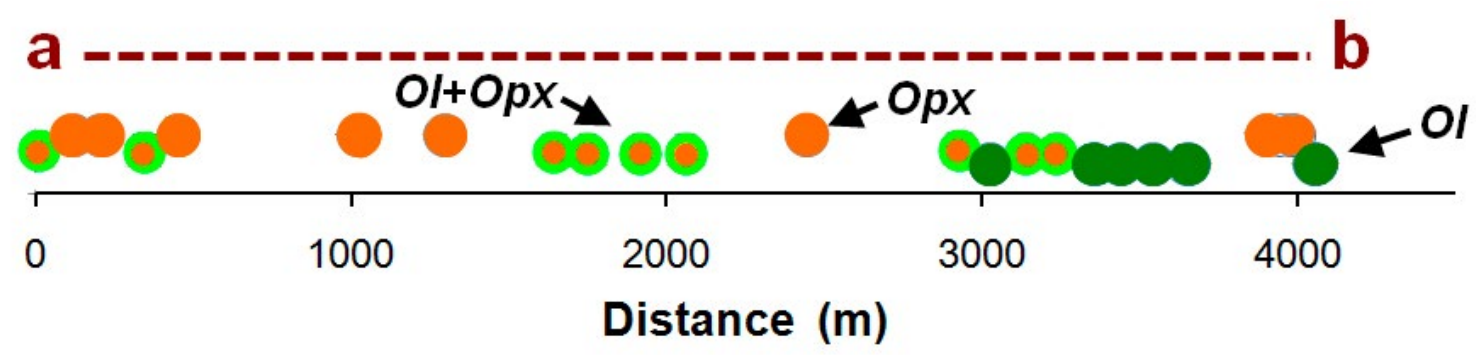

Figure 3. A schematic representation of the location of olivine (OI), orthopyroxene (Opx) and olivine-orthopyroxene $(\mathrm{Ol}+\mathrm{Opx})$ cumulates along the $a-b$ traverse (this study).

\section{Structure of the Pados- Tundra complex}

The satellite images (Fig. 6) seem to imply the existence of a concentric arrangement of layers that is not recognized on the geological map (cf. Fig. 2a). In addition, a semiconcentric fault (Fig. 6a) associated with a zone of intense foliation conforms to the concentrically layered arrangement. We presume that the complex is a lopolithic body which, in general, consists of primitive cumulates of the lower Dunite Zone (olivine cumulates) and orthopyroxene + olivine cumulates of the Orthopyroxenite Zone (Fig. 5). The complex was notably affected by tectonic events (presumably at 1.9-1.8 Ga); nevertheless, most of its blocks and fragments likely remained essentially in situ or moved short distances only, thus preserving the original structure recognizable in the satellite images. The differential rates of weathering, observed for olivine and orthopyroxene (Barkov et al., 2015, 2016), could have contributed to the formation of stepped-type relief as a result of the greater resistance of orthopyroxenite relative to dunite in surficial environments.

The concentric character of forms of relief (Fig. 6b) agrees well with the observed patterns of cryptic layering (Fig. 5a-f). Indeed, the traverse $a-b$ appears to be oriented across the layering rather than extending along a monotonous layer of orthopyroxenite, as is implied on the geological map (cf. Figs. 2a, 3).
As noted, most of the complex is composed of two major types of olivine-orthopyroxene rocks, including olivine cumulates of the Dunite Zone and combinations of the orthopyroxene-olivine cumulates interlayering along the traverse $a-b$ in the Orthopyroxenite Zone (Figs. 3, 4). The observed trends of cryptic layering (Fig. 5a-f) are consistent with a closed-system fractionation via a single influx of magma. Processes of layering in basic magma are still not completely understood, although there have been advances in this respect (e.g., Namur et al., 2015, and references therein).

The previous scheme by Mamontov \& Dokuchaeva (2005) suggests that chromitite layers of the Dunite block are located near the top of the layered sequence, in a direct contact with gabbroic rocks (Fig. 4); note that such relationships are not possible in the absence of intermediate noritegabbronorite units. In contrast, our findings show conclusively that this block, hosting the zones of Cr-PGE mineralization, occupies a lower structural position near the margin of the complex (Fig. 5). Indeed, compositions of chromian spinel $(M g \#$ of -0.6$)$ and olivine (up to $\mathrm{Fo}_{93}$; Barkov et al., 2017) documented in the mineralized samples of dunite and chromitite all are very magnesian in the Dunite block. On the basis of the observed extent of their $\mathrm{Mg}$-enrichment, they likely represent most primitive and early-crystallizing cumulates of the lowest portion of the magma chamber. The discrepancies observed between the previous and presently inferred schemes (cf. Figs. 4, 5) can be 


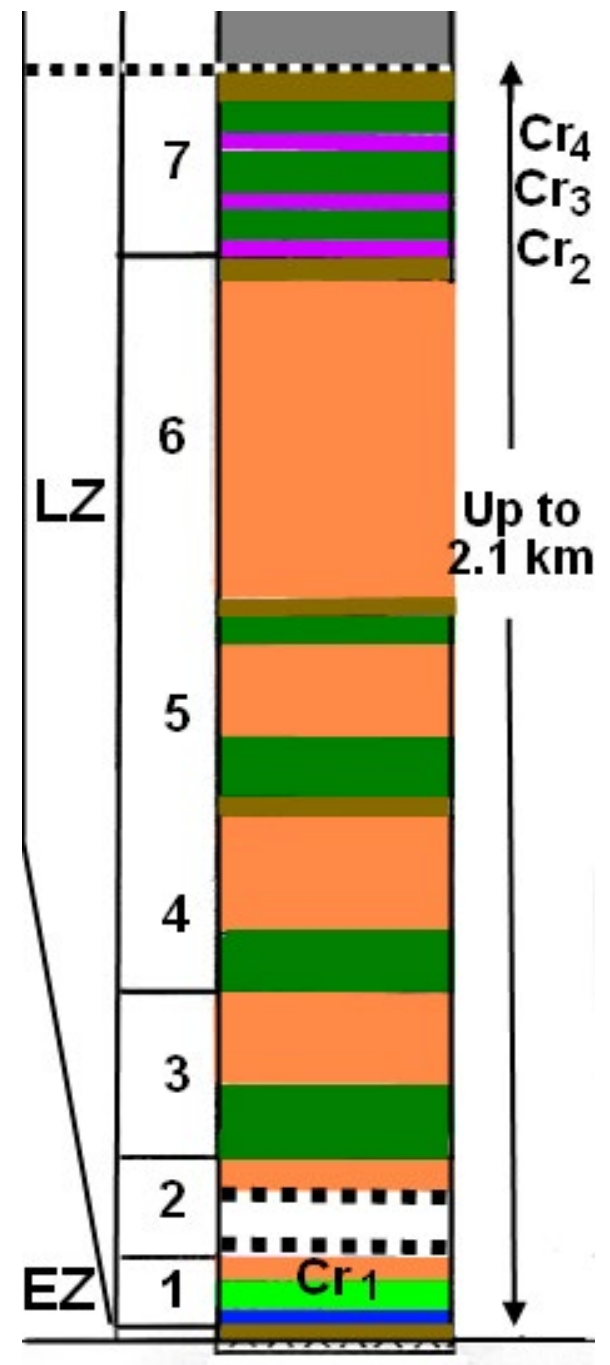

Figure 4. A generalized column (after Mamontov \& Dokuchaeva, 2005: see text for discussion), showing the layered sequence and the proposed position of chromitite layers in the northeastern portion of the complex; EZ is the endocontact zone; LZ is the layered zone; and numbers 1 to 7 pertain to the rhythmic layers proposed by these authors. The legend is the same as in Fig. 2; grey color refers to gabbroic rocks, which were proposed to overlie the chromitite-bearing dunite of the Dunite block; in contrast, we contend that this block appears to represent earliest cumulates of the lower structural level (this study). A zone of intense destruction is shown in white. ascribed to tectonic processes and displacements involving the Dunite block, which could have changed its original structure. Interestingly, the observed olivine-magnesiochromite association $\left(\mathrm{Fo}_{93}\right.$ and $M g \#$ of $\sim 0.6$, respectively) is strongly magnesian at Pados-Tundra; however, this association is even richer in $\mathrm{Mg}$ at Monchepluton, Kola Peninsula ( $\mathrm{Fo}_{96}$ and $M g \#$ of $\sim 0.7$; Barkov et al.; unpubl. data). The latter Fo value could well be close to an absolute maximum for layered intrusions.

\section{Traverses, samples and analytical data}

More than one hundred specimens were collected along the $-4-\mathrm{km}$ cross-section $a-b$ and along a north-south traverse $c-d$ oriented perpendicularly. In addition, a large number of outcrops were investigated and sampled in the Dunite block, which is the host for various and significant deposits of chromite (Fig. 2a). Unfortunately, GPS coordinates could not be provided because of special restrictions applied in the border area. In agreement with previous descriptions of Mamontov \& Dokuchaeva (2005), orthopyroxenite (typically $>95$ vol.\% orthopyroxene) and dunite ( $-90-95$ vol.\% olivine and minor orthopyroxene) are strongly dominant in the orthopyroxene-olivine ortho- or mesocumulates (e.g., Figs. 7, 8); olivinebearing orthopyroxenite ( $\leq 5$ vol.\% olivine) is relatively minor in the western portion. Harzburgite $(\neg 70$ vol.\% olivine) forms a layer in the $c-d$ crosssection (Fig. 2a). No grains of clinopyroxene or plagioclase were observed; highly magnesian amphiboles and subhedral grains of accessory chromite are common; magnesian ilmenite is rare in these associations. Deuteric $\mathrm{Cr}$-Al-enriched serpentine, too fine-grained to be macroscopically visible, is described in this study (Fig. 10; see section 5.5). Fairly fresh rocks are present in the outcrops, although the samples typically display a variable extent of secondary alteration reflected by the development of clinochlore, talc, serpentine, magnesite or dolomite. Base-metal sulfides are 


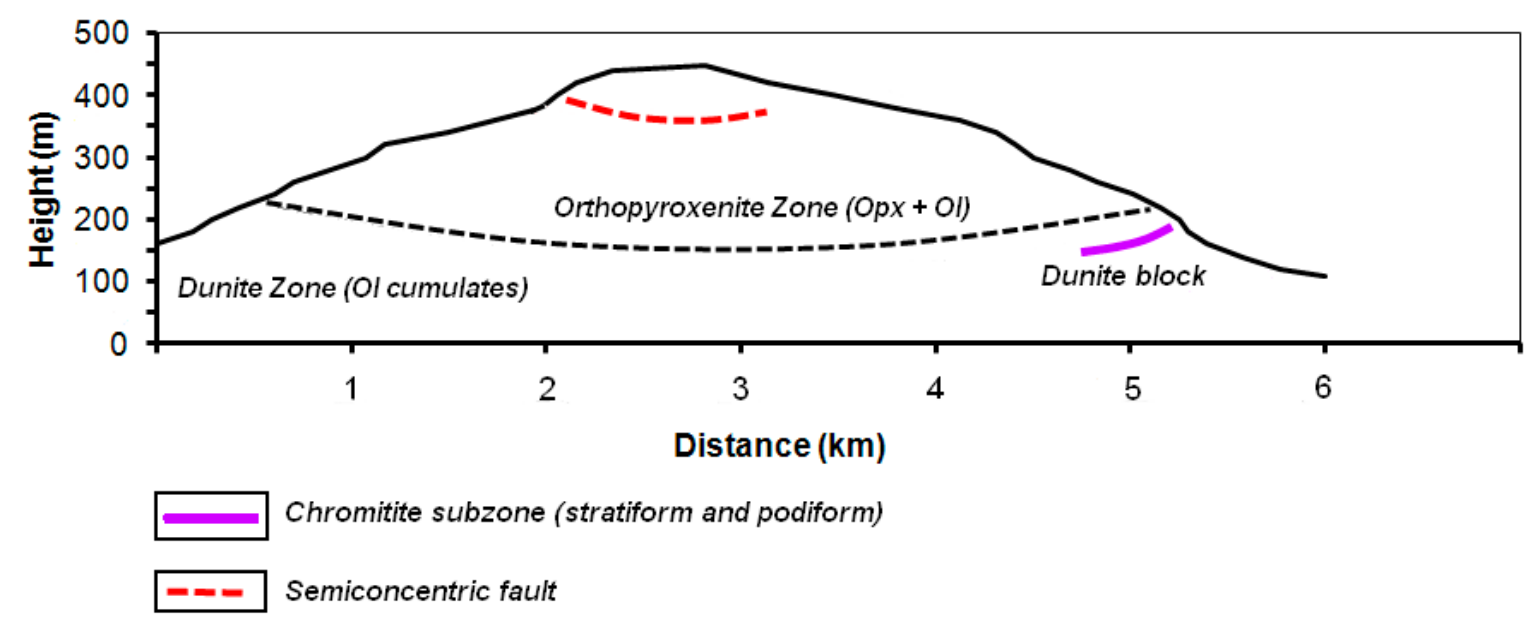

Figure 5. A sketch showing a generalized cross-section of layered series of the Pados-Tundra complex (this study); the lower Dunite Zone consists of olivine cumulates; the Orthopyroxenite Zone is dominated by orthopyroxene cumulates interlayered with olivine-bearing cumulates (Fig. 3).

scarce; they occur as small grains $(<0.1 \mathrm{~mm})$ of pentlandite (Co-bearing), pyrrhotite, and, locally, pyrite; millerite was only observed in chromitite of the Dunite block.

Twenty-five specimens collected along the traverse $a-b$ (Fig. 4) were chosen for a detailed electron-microprobe analysis (data presented in Tables 1-5). Note that (1) these samples appear to be representative of rocks remaining in situ in their lode outcrops. (2) They are typical of the surrounding cumulates. (3) They are fairly fresh, and contain only minor amounts of secondary minerals, which are deuterically induced. (4) They do not exhibit signs of deformation, and their primary magmatic textures are thus preserved very well. (5) The foliated areas were not sampled along the profile $a-b$ to study the cryptic layering; also, some intervals, without proper exposures of bedrock, could not be sampled. The minerals were analyzed in polished sections in situ at the Sobolev Institute of Geology and Mineralogy, Siberian Branch of the Russian Academy of Sciences, Novosibirsk, in wavelength-dispersion spectrometry (WDS) mode using a JEOL JXA-8200 electron microprobe operated at 20 $\mathrm{kV}$ and $100 \mathrm{nA}$ for olivine and $50 \mathrm{nA}$ for hydrous silicates. A finely focused beam $(1 \mu \mathrm{m})$ was applied. As vanadium was sought, the $\mathrm{Cr} K \beta_{1} \mathrm{X}$-ray line was used for Cr. The $K \alpha_{1}$ line was used for other elements. Olivine (for $\mathrm{Mg}, \mathrm{Si}, \mathrm{Fe}$, and $\mathrm{Ni}$ ) and chromiferous or manganiferous garnet $(\mathrm{Cr}$ and $\mathrm{Mn}$ ) were used as standards for olivine. The WDS data for other minerals were acquired using a pyrope standard for $\mathrm{Mg}$ and $\mathrm{Al}$, diopside for $\mathrm{Ca}$ and $\mathrm{Si}$, albite $(\mathrm{Na})$, orthoclase $(\mathrm{K}), \mathrm{V}_{2} \mathrm{O}_{5}(\mathrm{~V}), \mathrm{NiFe}_{2} \mathrm{O}_{4}(\mathrm{Ni})$, and rutile $(\mathrm{Ti})$. The results were processed with a ZAF program. The calculated values of minimum detection limit (MDL) in the WDS analyses of olivine are: 0.01 wt. $\%$ for $\mathrm{Cr}$ and $<0.01$ wt. $\%$ for $\mathrm{Ni}, \mathrm{Ca}$, and $\mathrm{Mn}$. The MDL values in analyses of other minerals are: 0.01 wt.\% (Al, Ni, V, Mn, K, and $\mathrm{Ca}$ ), 0.02 wt.\% (Na, Ti), and 0.04 wt.\% for Cr. The accuracy and reproducibility of analytical procedures were evaluated with special tests (Korolyuk et al., 2009; Lavrent' ev et al., 2015). 


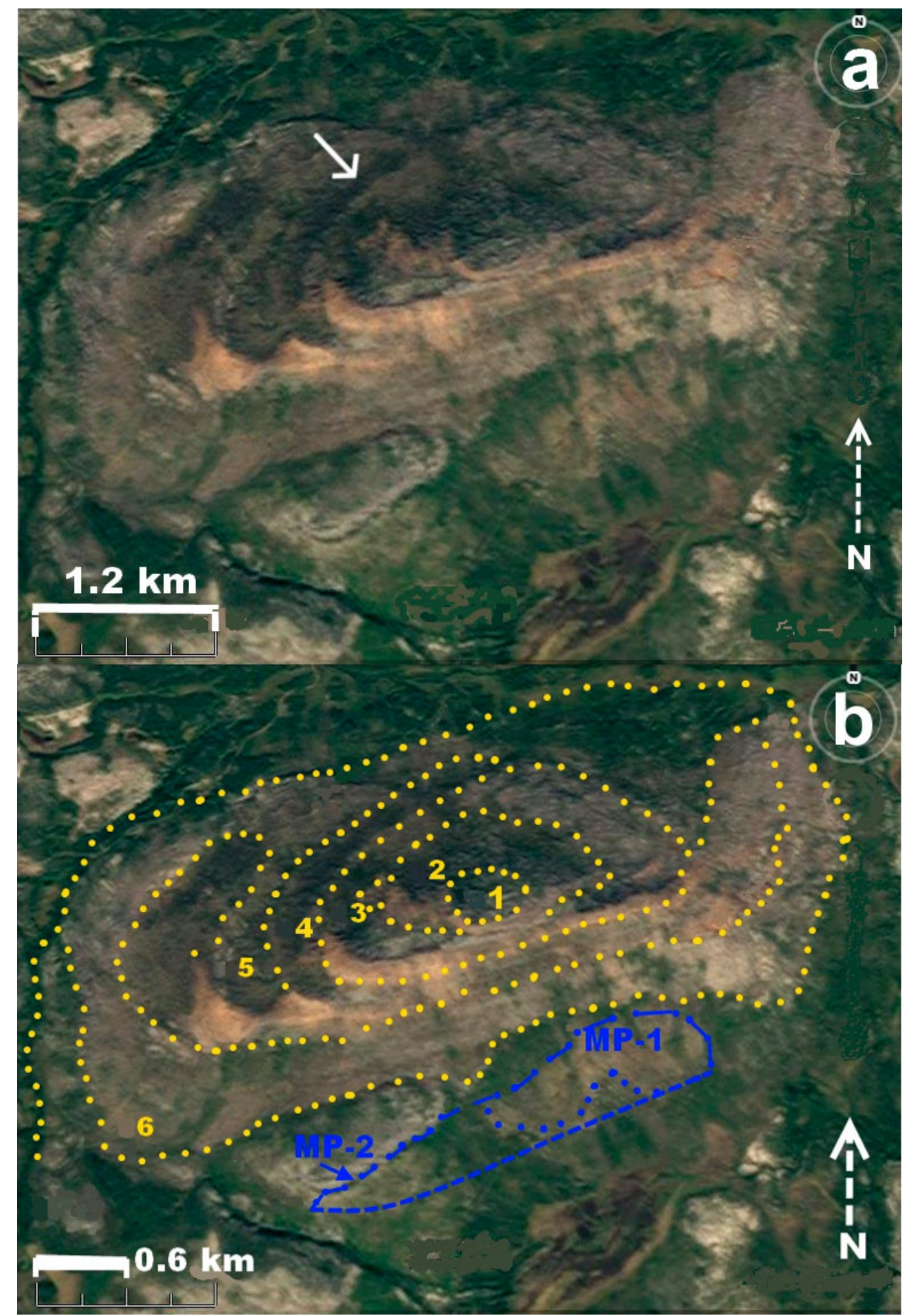

Figure 6. (a) A satellite image obtained via the "Google Earth", which show the Pados-Tundra complex under different regimes of satellite-imposed topography, and (b) a generalized interpretation of the concentrically layered arrangement based on the satellite image. The six areas (labeled " 1 " to "6") are hypothetically outlined. The label "MP" pertains to area of abundances of large blocks that form part of the Malyi Pados massif, i.e., presumably, large fragments detached from the Pados-Tundra complex. Map data (c) 2016 Google Image Landsat. 
Table 1. Compositions of olivine in the Pados-Tundra complex, Kola Peninsula, Russia.

\begin{tabular}{llccccccccccc}
\hline & Sample & $(\mathrm{m})$ & $\mathrm{SiO}_{2}$ & $\mathrm{Cr}_{2} \mathrm{O}_{3}$ & $\mathrm{FeO}$ & $\mathrm{MnO}$ & $\mathrm{MgO}$ & $\mathrm{NiO}$ & $\mathrm{CaO}$ & Total & Fo & Fa \\
\hline & & & wt.\% & & & & & & & & \\
1 & Pds-1 & 50 & 41.19 & 0.01 & 8.63 & 0.12 & 49.80 & 0.49 & 0.02 & 100.27 & 90.6 & 8.8 \\
2 & Pds-8 & 350 & 40.76 & 0.03 & 11.37 & 0.24 & 47.54 & 0.32 & $\leq 0.01$ & 100.26 & 87.7 & 11.8 \\
3 & Pds-41 & 1650 & 40.82 & 0.05 & 11.59 & 0.15 & 47.18 & 0.33 & 0.01 & 100.12 & 87.5 & 12.1 \\
4 & Pds-41b & 1650 & 40.77 & 0.04 & 11.88 & 0.16 & 47.00 & 0.32 & 0.01 & 100.18 & 87.1 & 12.4 \\
5 & Pds-44 & 1745 & 40.47 & $\leq 0.01$ & 12.37 & 0.17 & 47.05 & 0.29 & $\leq 0.01$ & 100.35 & 86.7 & 12.8 \\
6 & Pds-50 & 1915 & 40.46 & $\leq 0.01$ & 13.27 & 0.20 & 45.62 & 0.32 & 0.01 & 99.88 & 85.5 & 14.0 \\
7 & Pds-50b & 1915 & 40.40 & $\leq 0.01$ & 13.30 & 0.20 & 45.61 & 0.32 & 0.01 & 99.84 & 85.5 & 14.0 \\
8 & Pds-54 & 2060 & 40.73 & 0.01 & 12.59 & 0.19 & 46.08 & 0.30 & 0.01 & 99.90 & 86.3 & 13.2 \\
9 & Pds-75 & 2925 & 40.55 & $\leq 0.01$ & 12.55 & 0.15 & 46.83 & 0.34 & 0.02 & 100.44 & 86.5 & 13.0 \\
10 & Pds-77 & 3025 & 40.29 & 0.02 & 13.07 & 0.21 & 46.23 & 0.33 & 0.01 & 100.16 & 85.8 & 13.6 \\
11 & Pds-77b & 3025 & 40.33 & 0.22 & 12.72 & 0.20 & 46.27 & 0.29 & 0.08 & 100.11 & 86.1 & 13.3 \\
12 & Pds-80 & 3145 & 40.51 & $\leq 0.01$ & 12.85 & 0.18 & 45.92 & 0.32 & 0.01 & 99.78 & 86.0 & 13.5 \\
13 & Pds-82 & 3215 & 40.46 & 0.02 & 12.87 & 0.18 & 46.46 & 0.33 & 0.03 & 100.34 & 86.1 & 13.4 \\
14 & Pds-86 & 3355 & 39.68 & 0.02 & 11.19 & 0.17 & 48.00 & 0.34 & 0.02 & 99.42 & 88.0 & 11.5 \\
15 & Pds-88 & 3440 & 40.40 & 0.05 & 11.80 & 0.18 & 47.31 & 0.38 & 0.02 & 100.13 & 87.2 & 12.2 \\
16 & Pds-90 & 3540 & 40.86 & 0.02 & 11.70 & 0.16 & 47.13 & 0.33 & 0.01 & 100.20 & 87.3 & 12.2 \\
17 & Pds-90b & 3540 & 40.17 & $\leq 0.01$ & 11.44 & 0.17 & 47.60 & 0.36 & 0.03 & 99.76 & 87.6 & 11.8 \\
18 & Pds-93 & 3650 & 39.87 & 0.01 & 11.91 & 0.18 & 47.60 & 0.36 & $\leq 0.01$ & 99.93 & 87.2 & 12.2 \\
19 & Pds-97 & 4055 & 41.32 & 0.03 & 9.79 & 0.18 & 48.67 & 0.39 & 0.01 & 100.39 & 89.3 & 10.1 \\
20 & Pds-97b & 4055 & 41.18 & 0.01 & 9.82 & 0.17 & 48.79 & 0.38 & 0.01 & 100.35 & 89.4 & 10.1 \\
\hline
\end{tabular}

These results of WDS analyses were acquired with a JEOL JXA-8200 electron microprobe. $\mathrm{Na}, \mathrm{K}, \mathrm{Ti}, \mathrm{Al}$, and V were sought, but not detected. $(\mathrm{m})$ indicates the length of the traverse $a-b$ (Fig. 2a) from west to east.

\section{Discussion of results and implications}

\subsection{Cryptic variations in olivine and Ca-poor pyroxene}

Figures 7 and 8 show typical textures and mineral associations of olivine-orthopyroxene cumulates in samples of orthopyroxenite, olivine-bearing orthopyroxenite and dunite. The overall variations established in the present study of the complex for olivine are: $\mathrm{Fo}_{85.5-90.6}$, with $0.26-0.49$ wt.\% NiO and $0.12-0.24$ wt. $\% \mathrm{MnO}$; they are based on WDS results acquired on 50 grains. Evolutionary trends of crystallization of $\mathrm{Ol}$ are expressed in terms of Fo or $\mathrm{Fa}$ and minor contents of $\mathrm{Ni}$ in representative specimens sampled along the traverse $a-b$ (Fig. $11 \mathrm{a}-\mathrm{c}$; Table 1). These variations indicate that the lower levels of the ultramafic intervals are, in general, exposed successively toward the outer contact. The documented range is narrower in the samples collected along the profile $c-d: \mathrm{Fo}_{87.1-89.0}$, with a slight tendency for Fo to increase outward.

Calcium-poor pyroxene (seventy grains analyzed) covers the range $\left[\mathrm{Wo}_{<0.1-3.0} \mathrm{En}_{85.1-}\right.$ ${ }_{91.2} \mathrm{Fs}_{8.1-12.5}$ ], with 0.03-1.55 wt.\% CaO, 0.10-0.23 wt.\% $\mathrm{MnO}, 0.03-0.14$ wt.\% $\mathrm{NiO}, \leq 0.02-1.47$ wt. $\% \mathrm{Al}_{2} \mathrm{O}_{3}, \leq 0.04-1.08$ wt. $\% \mathrm{Cr}_{2} \mathrm{O}_{3}, \leq 0.01-0.05$ wt. $\% \mathrm{~V}_{2} \mathrm{O}_{3}$, and $\leq 0.02-0.1$ wt. $\% \mathrm{TiO}_{2}$. They all represent orthopyroxene; two specimens, collected close to outer contact of the complex, contain two compositions of orthopyroxene, possibly attributable to an alteration relationship (Fig. 8c; Pds-96 and Pds-110, respectively; Table 2). The second generation of orthopyroxene, possibly precipitated from a high-temperature hydrothermal fluid (cf. Akizawa \& Arai, 2014), replaces the host phase of orthopyroxene. Interestingly, metastable conditions of crystallization, existing in marginal 
Table 2. Compositions of Ca-poor pyroxene in the Pados-Tundra complex, Kola Peninsula.

\begin{tabular}{|c|c|c|c|c|c|c|c|c|c|c|}
\hline & Sample & (m) & $\mathrm{SiO}_{2}$ & $\mathrm{TiO}_{2}$ & $\mathrm{Al}_{2} \mathrm{O}_{3}$ & $\mathrm{Cr}_{2} \mathrm{O}_{3}$ & $\mathrm{~V}_{2} \mathrm{O}_{3}$ & $\mathrm{FeO}$ & $\mathrm{MnO}$ & MgO \\
\hline & & & wt.\% & & & & & & & \\
\hline 1 & Pds-1 & 50 & 57.02 & 0.05 & 1.20 & 1.08 & 0.01 & 5.45 & 0.12 & 33.72 \\
\hline 2 & Pds-1a & 50 & 58.71 & 0.00 & 0.03 & 0.16 & n.d. & 5.82 & 0.14 & 35.26 \\
\hline 3 & Pds-3 & 120 & 57.46 & 0.05 & 1.14 & 0.76 & n.d. & 5.45 & 0.14 & 33.52 \\
\hline 4 & Pds-5 & 210 & 57.05 & 0.06 & 1.15 & 0.84 & n.d. & 5.37 & 0.16 & 33.77 \\
\hline 5 & Pds-8 & 350 & 57.10 & 0.05 & 1.16 & 0.62 & n.d. & 6.04 & 0.14 & 33.28 \\
\hline 6 & Pds-11 & 455 & 57.02 & 0.04 & 1.30 & 0.49 & n.d. & 5.94 & 0.13 & 32.99 \\
\hline 7 & Pds-30 & 1300 & 56.29 & 0.07 & 1.07 & 0.70 & 0.01 & 7.36 & 0.17 & 32.50 \\
\hline 8 & Pds-41 & 1650 & 56.46 & 0.05 & 1.01 & 0.73 & 0.05 & 7.51 & 0.17 & 32.95 \\
\hline 9 & Pds-44 & 1745 & 55.99 & 0.07 & 1.02 & 0.68 & 0.01 & 7.20 & 0.17 & 32.56 \\
\hline 10 & Pds-50 & 1915 & 56.65 & 0.04 & 0.97 & 0.62 & 0.01 & 7.40 & 0.20 & 32.77 \\
\hline 11 & Pds-54 & 2060 & 56.38 & 0.06 & 0.99 & 0.68 & n.d. & 7.37 & 0.20 & 32.78 \\
\hline 12 & Pds-75 & 2925 & 56.29 & 0.04 & 1.03 & 0.76 & n.d. & 7.55 & 0.20 & 32.93 \\
\hline 13 & Pds-80 & 3145 & 57.10 & 0.04 & 0.97 & 0.65 & n.d. & 7.39 & 0.18 & 32.10 \\
\hline 14 & Pds-82 & 3215 & 56.80 & 0.03 & 1.00 & 0.81 & 0.01 & 7.60 & 0.21 & 32.15 \\
\hline 15 & Pds-94 & 3900 & 57.17 & 0.06 & 1.23 & 0.48 & 0.01 & 6.12 & 0.13 & 32.84 \\
\hline 16 & Pds-95 & 3950 & 56.40 & 0.07 & 1.40 & 0.75 & 0.02 & 5.86 & 0.13 & 32.81 \\
\hline 17 & Pds-96a & 3985 & 57.51 & 0.01 & 0.05 & 0.21 & 0.01 & 7.67 & 0.16 & 33.80 \\
\hline 18 & Pds-96b & 3985 & 57.43 & 0.03 & 0.25 & 0.09 & n.d. & 7.66 & 0.15 & 33.69 \\
\hline 19 & Pds-96c & 3985 & 56.45 & 0.04 & 1.43 & 0.50 & 0.01 & 7.39 & 0.15 & 31.91 \\
\hline 20 & Pds-96d & 3985 & 57.04 & 0.05 & 0.68 & 0.45 & n.d. & 7.82 & 0.15 & 32.47 \\
\hline 21 & Pds-110 & prx-1 & 57.43 & 0.04 & 0.03 & 0.16 & n.d. & 7.93 & 0.20 & 33.69 \\
\hline 22 & Pds-110 & prx-2 & 57.40 & 0.03 & 0.03 & 0.00 & n.d. & 8.01 & 0.22 & 33.28 \\
\hline 23 & Pds-110 & prx-3 & 56.35 & 0.08 & 1.20 & 0.59 & 0.02 & 7.27 & 0.17 & 32.01 \\
\hline 24 & Pds-110 & prx-4 & 56.47 & 0.06 & 1.21 & 0.52 & 0.01 & 7.17 & 0.16 & 31.94 \\
\hline
\end{tabular}

Table 2 continued

\begin{tabular}{|c|c|c|c|c|c|c|c|c|}
\hline & $\mathrm{NiO}$ & $\mathrm{CaO}$ & $\mathrm{Na}_{2} \mathrm{O}$ & $\mathrm{K}_{2} \mathrm{O}$ & Total & Wo & En & Fs \\
\hline & wt.\% & & & & & & & \\
\hline 1 & 0.11 & 1.27 & 0.03 & n.d. & 100.08 & 2.4 & 89.2 & 8.3 \\
\hline 2 & 0.10 & 0.06 & n.d. & n.d. & 100.27 & 0.1 & 91.2 & 8.7 \\
\hline 3 & 0.09 & 1.24 & 0.08 & n.d. & 99.94 & 2.4 & 89.0 & 8.3 \\
\hline 4 & 0.12 & 1.24 & 0.10 & 0.01 & 99.87 & 2.4 & 89.1 & 8.2 \\
\hline 5 & 0.07 & 1.28 & 0.06 & n.d. & 99.81 & 2.4 & 88.2 & 9.2 \\
\hline 6 & 0.10 & 1.33 & 0.09 & 0.01 & 99.44 & 2.5 & 88.0 & 9.1 \\
\hline 7 & 0.12 & 1.15 & 0.06 & n.d. & 99.49 & 2.2 & 86.4 & 11.2 \\
\hline 8 & 0.09 & 1.15 & 0.04 & n.d. & 100.20 & 2.2 & 86.4 & 11.3 \\
\hline 9 & 0.10 & 1.18 & 0.05 & n.d. & 99.04 & 2.3 & 86.6 & 11.0 \\
\hline 10 & 0.12 & 1.14 & 0.02 & n.d. & 99.93 & 2.2 & 86.5 & 11.3 \\
\hline 11 & 0.12 & 1.22 & 0.04 & 0.01 & 99.84 & 2.3 & 86.3 & 11.2 \\
\hline 12 & 0.07 & 1.16 & 0.04 & n.d. & 100.07 & 2.2 & 86.3 & 11.4 \\
\hline 13 & 0.11 & 1.13 & 0.09 & 0.01 & 99.77 & 2.2 & 86.1 & 11.4 \\
\hline 14 & 0.11 & 1.15 & n.d. & n.d. & 99.86 & 2.2 & 86.1 & 11.7 \\
\hline 15 & 0.11 & 1.34 & 0.04 & n.d. & 99.53 & 2.6 & 87.9 & 9.4 \\
\hline 16 & 0.11 & 1.46 & 0.06 & n.d. & 99.08 & 2.8 & 87.9 & 9.0 \\
\hline 17 & 0.08 & 0.05 & n.d. & 0.01 & 99.56 & 0.1 & 88.4 & 11.5 \\
\hline 18 & 0.06 & 0.29 & n.d. & n.d. & 99.65 & 0.5 & 88.0 & 11.4 \\
\hline 19 & 0.06 & 1.41 & 0.06 & n.d. & 99.40 & 2.7 & 85.7 & 11.4 \\
\hline 20 & 0.04 & 0.88 & n.d. & n.d. & 99.57 & 1.7 & 86.4 & 11.9 \\
\hline 21 & 0.03 & 0.06 & n.d. & n.d. & 99.56 & 0.1 & 88.0 & 11.9 \\
\hline 22 & 0.05 & 0.05 & n.d. & n.d. & 99.06 & 0.1 & 87.7 & 12.2 \\
\hline 23 & 0.13 & 1.46 & 0.07 & n.d. & 99.33 & 2.8 & 85.8 & 11.2 \\
\hline 24 & 0.11 & 1.44 & 0.08 & n.d. & 99.17 & 2.8 & 85.9 & 11.1 \\
\hline
\end{tabular}

n.d. $=$ not detected 
Table 3. Compositions of tremolite in the Pados-Tundra complex, Kola Peninsula.

\begin{tabular}{|c|c|c|c|c|c|c|c|c|c|c|c|c|c|}
\hline & & & & & (total) & & & & & & & & \\
\hline & $\mathrm{SiO}_{2}$ & $\mathrm{TiO}_{2}$ & $\mathrm{Al}_{2} \mathrm{O}_{3}$ & $\mathrm{Cr}_{2} \mathrm{O}_{3}$ & $\mathrm{FeO}$ & $\mathrm{MnO}$ & MgO & $\mathrm{NiO}$ & $\mathrm{CaO}$ & $\mathrm{Na}_{2} \mathrm{O}$ & $\mathrm{K}_{2} \mathrm{O}$ & Total & Mg\# \\
\hline & wt.\% & & & & & & & & & & & & \\
\hline 1 & 58.70 & $\leq 0.02$ & 0.15 & 0.31 & 4.38 & 0.19 & 25.54 & 0.06 & 9.36 & 0.08 & $\leq 0.01$ & 98.76 & 0.92 \\
\hline 2 & 58.20 & 0.04 & 0.21 & 0.18 & 2.86 & 0.12 & 23.50 & 0.08 & 11.68 & 0.18 & 0.01 & 97.06 & 0.94 \\
\hline 3 & 58.60 & 0.02 & 0.26 & 0.15 & 2.33 & 0.10 & 23.04 & 0.10 & 12.58 & 0.17 & 0.02 & 97.35 & 0.95 \\
\hline 4 & 58.26 & 0.04 & 0.38 & 0.26 & 2.16 & 0.11 & 23.82 & 0.07 & 11.99 & 0.12 & 0.01 & 97.22 & 0.95 \\
\hline 5 & 58.44 & 0.04 & 0.33 & 0.02 & 2.10 & 0.10 & 23.14 & 0.09 & 12.62 & 0.19 & 0.02 & 97.09 & 0.95 \\
\hline 6 & 58.50 & $\leq 0.02$ & 0.12 & 0.17 & 2.27 & 0.13 & 23.01 & 0.03 & 13.13 & 0.13 & 0.01 & 97.52 & 0.95 \\
\hline 7 & 58.68 & 0.03 & 0.24 & $\leq 0.04$ & 2.42 & 0.12 & 23.10 & 0.09 & 12.41 & 0.23 & 0.01 & 97.32 & 0.94 \\
\hline 8 & 58.69 & $\leq 0.02$ & 0.29 & 0.11 & 2.70 & 0.13 & 22.55 & 0.08 & 12.99 & 0.18 & 0.03 & 97.75 & 0.94 \\
\hline 9 & 58.24 & 0.02 & 0.34 & 0.17 & 2.75 & 0.14 & 22.20 & 0.07 & 12.72 & 0.18 & 0.03 & 96.87 & 0.94 \\
\hline 10 & 58.39 & 0.02 & 0.32 & 0.22 & 2.40 & 0.10 & 22.79 & 0.10 & 12.57 & 0.21 & 0.01 & 97.15 & 0.94 \\
\hline 11 & 58.36 & 0.02 & 0.21 & 0.12 & 2.65 & 0.11 & 23.38 & 0.12 & 11.96 & 0.21 & $\leq 0.01$ & 97.13 & 0.94 \\
\hline 12 & 59.01 & $\leq 0.02$ & 0.30 & 0.21 & 1.67 & 0.09 & 23.19 & 0.11 & 12.79 & 0.11 & 0.02 & 97.50 & 0.96 \\
\hline 13 & 59.36 & 0.03 & 0.18 & 0.16 & 1.64 & 0.10 & 23.23 & 0.10 & 12.72 & 0.12 & 0.02 & 97.69 & 0.96 \\
\hline 14 & 58.66 & 0.08 & 0.51 & $\leq 0.04$ & 1.83 & 0.05 & 23.61 & 0.13 & 12.18 & 0.07 & 0.03 & 97.16 & 0.96 \\
\hline 15 & 58.46 & 0.07 & 0.72 & $\leq 0.04$ & 1.78 & 0.07 & 23.19 & 0.13 & 12.34 & 0.27 & 0.03 & 97.06 & 0.96 \\
\hline 16 & 58.35 & 0.05 & 0.29 & 0.21 & 2.86 & 0.08 & 24.46 & 0.11 & 10.67 & 0.12 & 0.02 & 97.22 & 0.94 \\
\hline 17 & 58.08 & 0.03 & 0.50 & 0.30 & 1.99 & 0.09 & 23.31 & 0.11 & 12.61 & 0.19 & 0.04 & 97.26 & 0.95 \\
\hline 18 & 58.25 & 0.03 & 0.35 & $\leq 0.04$ & 1.98 & 0.09 & 23.30 & 0.09 & 12.71 & 0.21 & 0.04 & 97.10 & 0.95 \\
\hline 19 & 58.43 & 0.02 & 0.20 & 0.35 & 1.65 & 0.05 & 23.33 & 0.09 & 12.86 & 0.10 & 0.02 & 97.11 & 0.96 \\
\hline 20 & 59.00 & 0.06 & 0.05 & $\leq 0.04$ & 1.24 & 0.03 & 23.39 & 0.09 & 13.35 & 0.10 & 0.02 & 97.32 & 0.97 \\
\hline
\end{tabular}

Note. These results of WDS analyses were acquired with a JEOL JXA-8200 electron microprobe. Number 1 pertains to sample Pds-50; no. 2, 3 to Pds-54; no. 4, 5 to Pds-64; no. 6 to Pds-75; no. 7 to Pds-77; no. 8 to Pds-80; no. 9,10 to Pds-82; no. 11 to Pds-93; no. 12 , 13 to Pds-97; no. 14, 15 to Pds-94; no. 16 to Pds-107; no. 17, 18 to Pds-108; no. 19, 20 to Pds-111. Contents of $\mathrm{V}_{2} \mathrm{O}_{3}$ are $\leq 0.01$ wt.\% in all of these datasets. The $\mathrm{Mg} \#$ index is $\mathrm{Mg} /(\mathrm{Mg}+\mathrm{Fe})$.

Table 4. Compositions of anthophyllite in the Pados-Tundra complex, Kola Peninsula.

\begin{tabular}{|c|c|c|c|c|c|c|c|c|c|c|c|c|c|}
\hline & & & & & (total) & & & & & & & & \\
\hline & $\mathrm{SiO}_{2}$ & $\mathrm{TiO}_{2}$ & $\mathrm{Al}_{2} \mathrm{O}_{3}$ & $\mathrm{Cr}_{2} \mathrm{O}_{3}$ & $\mathrm{FeO}$ & $\mathrm{MnO}$ & $\mathrm{MgO}$ & $\mathrm{NiO}$ & $\mathrm{CaO}$ & $\mathrm{Na}_{2} \mathrm{O}$ & $\mathrm{K}_{2} \mathrm{O}$ & Total & Mg\# \\
\hline & wt.\% & & & & & & & & & & & & \\
\hline 1 & 58.91 & $\leq 0.02$ & 0.08 & $\leq 0.04$ & 9.19 & 0.29 & 27.96 & 0.09 & 1.22 & 0.03 & 0.01 & 97.79 & 0.84 \\
\hline 2 & 59.07 & $\leq 0.02$ & 0.03 & $\leq 0.04$ & 8.97 & 0.28 & 28.49 & 0.10 & 0.51 & 0.03 & $\leq 0.01$ & 97.50 & 0.85 \\
\hline 3 & 58.23 & 0.04 & 0.03 & 0.08 & 9.82 & 0.36 & 29.46 & 0.09 & 0.49 & $\leq 0.02$ & $\leq 0.01$ & 98.59 & 0.88 \\
\hline 4 & 58.70 & $\leq 0.02$ & 0.03 & $\leq 0.04$ & 9.64 & 0.37 & 29.56 & 0.10 & 0.51 & 0.05 & $\leq 0.01$ & 98.96 & 0.87 \\
\hline 5 & 58.72 & $\leq 0.02$ & 0.02 & 0.08 & 9.63 & 0.35 & 29.40 & 0.10 & 0.61 & $\leq 0.02$ & 0.01 & 98.93 & 0.87 \\
\hline 6 & 58.98 & $\leq 0.02$ & 0.04 & 0.17 & 9.56 & 0.38 & 28.86 & 0.09 & 1.07 & 0.02 & 0.01 & 99.17 & 0.86 \\
\hline 7 & 58.75 & $\leq 0.02$ & 0.03 & 0.12 & 10.09 & 0.44 & 28.64 & 0.10 & 0.74 & 0.02 & $\leq 0.01$ & 98.94 & 0.85 \\
\hline 8 & 59.70 & $\leq 0.02$ & 0.06 & 0.07 & 8.20 & 0.28 & 29.66 & 0.13 & 0.53 & 0.03 & $\leq 0.01$ & 98.67 & 0.87 \\
\hline 9 & 58.92 & $\leq 0.02$ & 0.05 & $\leq 0.04$ & 9.50 & 0.39 & 27.49 & 0.09 & 0.91 & 0.02 & $\leq 0.01$ & 97.38 & 0.84 \\
\hline 10 & 58.87 & 0.02 & 0.05 & $\leq 0.04$ & 9.27 & 0.33 & 27.94 & 0.12 & 0.63 & $\leq 0.02$ & $\leq 0.01$ & 97.21 & 0.84 \\
\hline 11 & 58.86 & 0.03 & 0.07 & $\leq 0.04$ & 9.54 & 0.34 & 27.92 & 0.12 & 0.67 & $\leq 0.02$ & $\leq 0.01$ & 97.56 & 0.84 \\
\hline 12 & 59.03 & 0.02 & 0.03 & $\leq 0.04$ & 9.63 & 0.32 & 27.70 & 0.13 & 0.76 & 0.03 & $\leq 0.01$ & 97.64 & 0.84 \\
\hline 13 & 59.17 & 0.02 & 0.05 & 0.11 & 8.20 & 0.26 & 29.03 & 0.08 & 0.56 & 0.04 & $\leq 0.01$ & 97.52 & 0.86 \\
\hline 14 & 59.30 & $\leq 0.02$ & 0.03 & $\leq 0.04$ & 8.33 & 0.27 & 28.85 & 0.09 & 0.59 & 0.04 & $\leq 0.01$ & 97.51 & 0.86 \\
\hline 15 & 59.35 & 0.03 & 0.03 & 0.11 & 7.80 & 0.26 & 29.21 & 0.10 & 0.50 & 0.03 & $\leq 0.01$ & 97.41 & 0.87 \\
\hline
\end{tabular}

Note. These results of WDS analyses were acquired with a JEOL JXA-8200 electron microprobe. Numbers 1, 2 pertain to sample Pds-30; no. 3-5 to Pds-44; no. 6-8 to Pds-50; no. 9 to Pds-54; no. 10-12 to Pds-82; no. 13, 14 to Pds-96; and no. 15 pertains to sample Pds-107. Contents of $\mathrm{V}_{2} \mathrm{O}_{3}$ are $\leq 0.01 \mathrm{wt}$. $\%$ in all of these datasets. The $\mathrm{Mg} \#$ index is $\mathrm{Mg} /(\mathrm{Mg}+\mathrm{Fe})$. 
Figure 7. Characteristic textures and associations observed in ultramafic rocks of the Pados-Tundra complex; back-scattered electron images (BSE).

(a) The coexistence of grains of high-Mg olivine (Ol; $\mathrm{FO}_{85.5}$ ) and orthopyroxene $\left[\mathrm{Opx} ; \mathrm{Wo}_{2.2} \mathrm{En}_{86.6} \mathrm{Fs}_{11.2}\right]$; also present is amphibole (Amp) and accessory chromite (Chr, sample Pds-50). (b) Grains of olivine $\left(\mathrm{Ol} ; \mathrm{Fo}_{86.3}\right.$ ) are associated with cumulus grains of orthopyroxene $\left[\mathrm{Opx} ; \mathrm{Wo}_{2.3} \mathrm{En}_{86.5-}\right.$ $\left.{ }_{86.8} \mathrm{Fs}_{11.0-11.2}\right]$, which are replaced locally by minor clinochlore $(\mathrm{Clc})$ in sample Pds54. (c) Subhedral grains of amphibole (Amp) oriented nearly perpendicularly to each other, associated with olivine (OI; $\mathrm{Fo}_{86.1}$ ); serpentine (Srp) and talc (TlC) also are present (sample Pds-77). (d) The associated grains of orthopyroxene [Opx; $\mathrm{Wo}_{2.2} \mathrm{En}_{86.3} \mathrm{Fs}_{11.5}$ ] and olivine [OI; $\mathrm{Fo}_{86.0}$ ] in sample Pds-80; needle-like crystals of amphibole (Amp) are present.

Figure 8. BSE images of ultramafic cumulates of the Pados-Tundra complex. (a) A euhedral grain of amphibole (amp; tremolite) is observed at the boundary of cumulus grains of olivine $\left[\mathrm{Fo}_{87.9}\right]$ and orthopyroxene $\left[\mathrm{Wo}_{2.3} \mathrm{En}_{88.0-87.6} \mathrm{Fs}_{9.6-10.1}\right]$ in sample Pds-103; Tlc is talc. (b) Subhedral grains of amphibole (Amp) are hosted by olivine $\left(\mathrm{Fo}_{87.1}\right)$ in sample Pds-108. (c) Replacement relationships are present in the composite grain of pyroxene in sample Pds-110. The phase darker in the BSE, labeled "prx 1, 2", is comparatively poorer in $\mathrm{Ca}, \mathrm{Al}$, and $\mathrm{Cr}$, and has the composition $\left[\mathrm{Wo}_{0.1} \mathrm{En}_{87.0-88.0} \mathrm{Fs}_{11.9-12.2}\right]$ based on two WDS point-analyses. The host phase of pyroxene, "prx 3, 4" corresponds to: $\left[\mathrm{Wo}_{2.8} \mathrm{En}_{85.8-85.9} \mathrm{Fs}_{11.1-11.2}\right]$. (d) An olivine-based cumulate $\left[\mathrm{Fo}_{89.0} ; \mathrm{Pds}-111\right]$ contains subhedral grains of chromite (Chr); Tlc is talc.
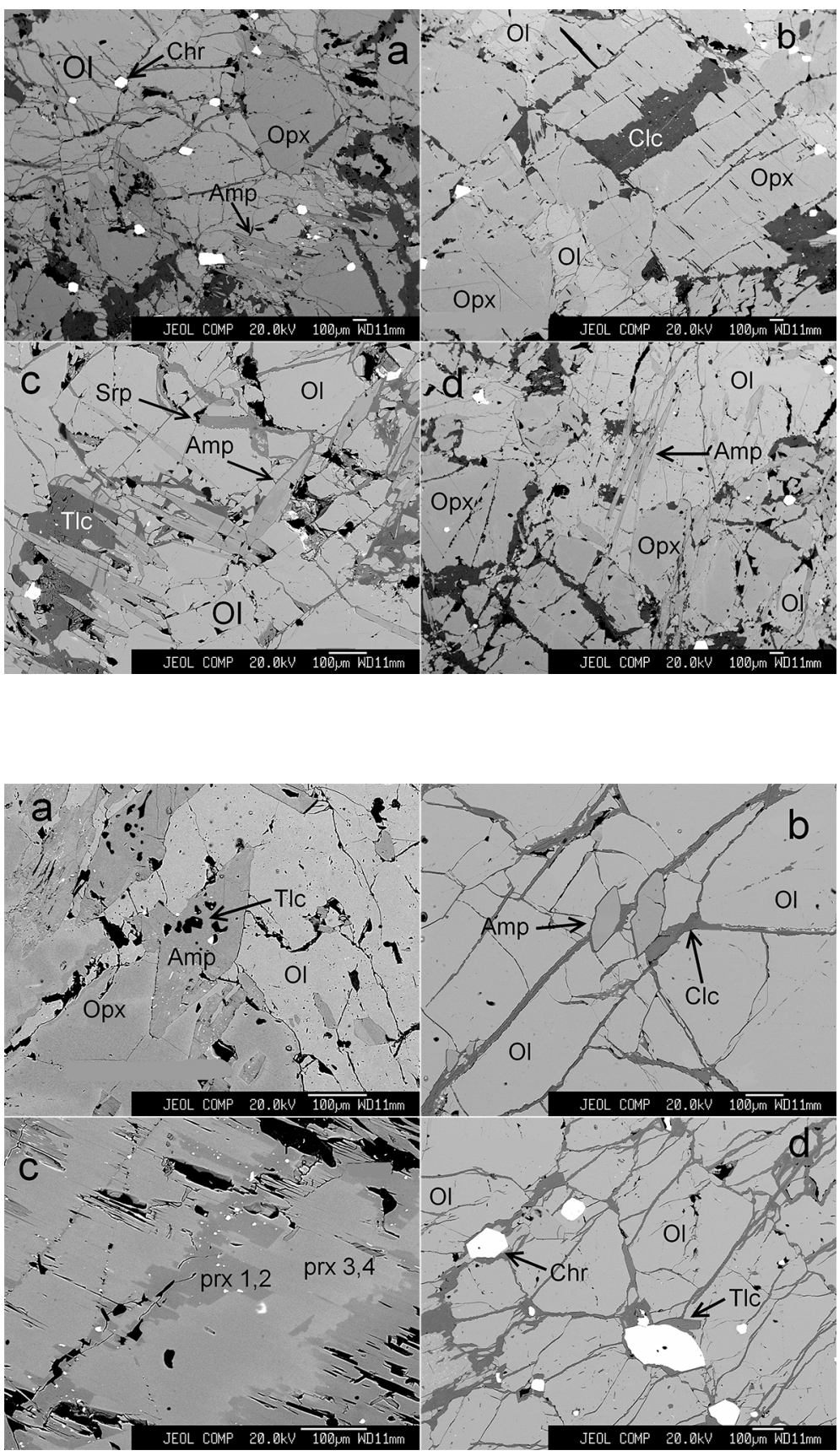
portions of complexes, can produce anomalous patterns of compositional zoning in pyroxene (Barkov \& Martin, 2015).

In general, the observed compositional trends are consistent for Ca-poor pyroxene and olivine (Fig. 11a-e). These patterns of cryptic layering indicate that ultramafic rocks in the central portion of the complex crystallized from a more evolved (fractionated) melt, relative to stratigraphically lower, early-crystallizing cumulates exposed closer to the outer contact. The observed variations of $\mathrm{Mn}$ content in the orthopyroxene (Fig. 12b, d) indicate that $\mathrm{Mn}$ is a sensitive reflection of the extent of fractional crystallization, as is the $\mathrm{Ni}$ content of olivine (Figs. 11c, 12c). In terms of the profile $a-b$, the contents of $\mathrm{Cr}$, and, less clearly, $\mathrm{Ni}$, tend to vary more importantly in compositions of pyroxene crystallizing closer to the margin of the complex (Figs. 11f, 12a). There is a positive $\mathrm{Cr}-\mathrm{Al}$ correlation (Fig. 13), which points to the coupled substitution $\left[\mathrm{Cr}^{3+}+\mathrm{Al}^{3+} \leftrightarrow \mathrm{Mg}^{2+}+\mathrm{Si}^{4+}\right]$, common in $\mathrm{Ca}$-poor pyroxene. The geochemical behavior of $\mathrm{Cr}$ is similar to that of $\mathrm{Ni}$ in the pyroxenes, as inferred from the slightly positive Ni-Cr correlation (Fig. 12f). The latter may reflect a subordinate exchange $\mathrm{Ni} \leftrightarrow \mathrm{Mg}\left(\mathrm{Fe}^{2+}\right)$ associated with the $\mathrm{Cr} \leftrightarrow \mathrm{Al}$ substitution.

\subsection{The most magnesian compositions of cumulus olivine and orthopyroxene}

The respective contents of Fo and En in the most strongly magnesian specimens of olivine and orthopyroxene, which appeared on the liquidus, allow us to evaluate the $M g \#$ of the parental magma. In the Fennoscandian Shield, a pyroxene of composition $\left[\mathrm{Mg}_{88} \mathrm{Fe}_{12}\right]$ is considered to be the earliest phase crystallizing in the ultramafic cumulates of the Näränkävaara layered complex in Finland; it corresponds to the most magnesian orthopyroxene in the lowest cumulates of the Bushveld and Jimberlana intrusions (Alapieti, 1982, and references therein). The compositions documented here, $\mathrm{Fo}_{91}$ olivine and $\mathrm{En}_{91}$ orthopyroxene, are notably more magnesian; they correspond to the most Mg-rich specimens reported from Great Dyke: $\mathrm{Fo}_{92}$ and $\mathrm{En}_{91.5}$ (Wilson, 1996). In addition, olivine of the same composition $\left(\mathrm{Fo}_{91}\right)$ is present in the Monchepluton complex, Kola Peninsula (Barkov et al., 2015). Therefore, a highly magnesian parental magma is indicated for the Pados-Tundra complex, likely close to the estimates made for the initial magma of the Great Dyke complex: $\sim 14$ wt. $\% \mathrm{MgO}$ (Stubbs et al., 1999) or, considered less likely, up to 115.6 wt.\% $\mathrm{MgO}$ (Wilson, 1996).

\subsection{Oikocrystic orthopyroxene and spheroidal patterns of weathering}

Oikocrystic spheres or ellipsoids of orthopyroxene in dunite (Fig. 9) $\left(\mathrm{Fo}_{87.0-87.5}:>90\right.$ vol.\% Ol), are locally abundant in the eastern portion of the PadosTundra complex. Related patterns of spheroidal weathering were documented in a chromite-rich harzburgite in the Monchepluton complex, Kola Peninsula (Barkov et al., 2015, 2016). At PadosTundra, the primary orthopyroxene is entirely replaced by deuteric talc and calcic amphibole (tremolite; $M g \#$ 95.4-95.9) in these oikocrysts. The oikocrystic grains of orthopyroxene are notably abundant in the Dunite block; they are rare in the other portions of the complex. The oikocrysts likely crystallized after the olivine from a fractionated melt. As a result of accumulation of volatiles, the primary oikocrysts were entirely replaced by talc and tremolite during a postmagmatic episode of hydrothermal alteration.

\subsection{Calcic and Fe-Mg amphiboles}

Amphiboles form subhedral to euhedral grains at grain boundaries of olivine and orthopyroxene (Figs. 7c-d, 8a-b); they are strongly subordinate, or are rare. There are inclusions of amphibole hosted by grains of olivine and orthopyroxene (e.g., Fig. 8b). Two species of amphiboles are recognized: tremolite and anthophyllite, both with high values of $M g \#$, which are slightly greater in tremolite (Tables 

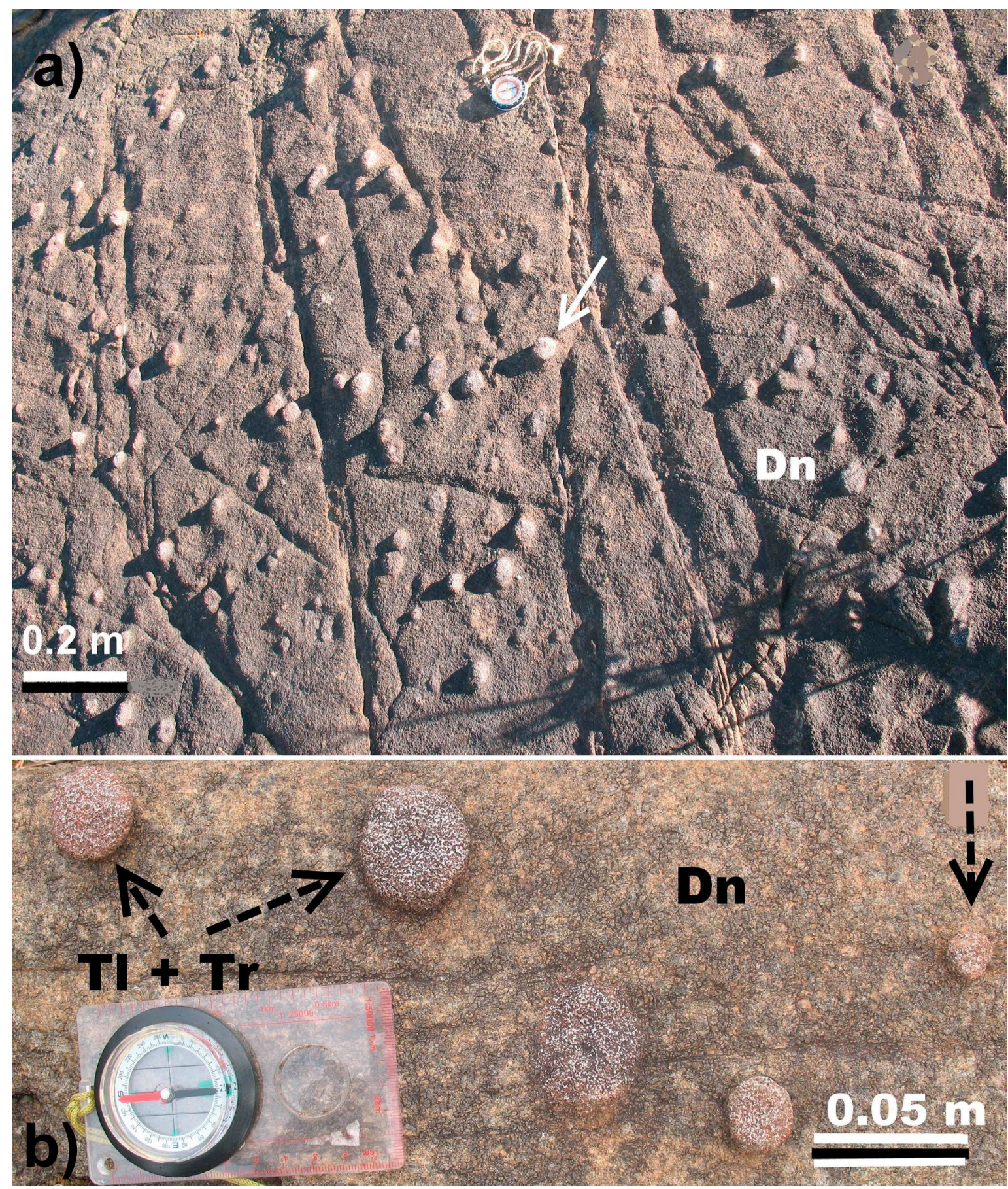

Figure 9. Outcrops of dunite (Dn) with relief spheroids, which are exposed on the weathered surface, and are caused by oikocrysts of Opx replaced entirely by deuterically induced talc (TI) and tremolite (Tr) (note the relief spheres shown by arrows in b), in the eastern portion of the Pados-Tundra complex. 
3, 4). Tremolite replaced grains and oikocrysts of orthopyroxene during the autometasomatic alteration.

Note that calcic amphibole is here the main Ca-rich phase. Indeed, Ca-rich pyroxene and plagioclase are virtually absent in the rocks at PadosTundra, in contrast to layered intrusions (2.4-2.5 Ga) in the Fennoscandian Shield (e.g., Alapieti et al., 1990; Barkov \& Nikiforov, 2016). This feature may well point to a fairly low content of $\mathrm{Ca}$ in the parental magma of the Pados-Tundra complex. Consequently, the fractionated melt became enriched in $\mathrm{Ca}$ only late in the crystallization history; the amphibole species crystallized as postmagmatic phases and during autometasomatic alteration. In relevant experiments, the association enstatite + quartz is converted to anthophyllite in the presence of $\mathrm{H}_{2} \mathrm{O}$ over a range of $670-800{ }^{\circ} \mathrm{C}$ at $2 \mathrm{kbar}$ (Fyfe, 1962); synthetic tremolite can form at $840{ }^{\circ} \mathrm{C}$ at $6 \mathrm{kbar}$ (Jenkins et al., 2013). In contrast, plagioclase is documented in the Chapes massif (or Chapes-Varaka), which is a lenticular body $(\sim 15 \times 0.7 \mathrm{~km})$ situated fairly close to Pados-Tundra in the Serpentinite belt (Gorbachova, 2000).

\subsection{Occurrences and implications of $\mathrm{Cr}$-Al-rich serpentine and extents of Cr enrichment in rock- forming and alteration minerals}

As in other ultramafic complexes, there are two modes of occurrence of serpentine at Pados-Tundra, i.e., deuterically induced and formed during regional metamorphism via alteration of olivine. We have analyzed veinlet-like grains of deuteric serpentine (Fig. 10) in slightly altered ultramafic rocks, in which the majority of grains of olivine and orthopyroxene are well preserved. The $\mathrm{Cr}$ content is low, $<0.1-0.2 \mathrm{wt} . \%$, in most of the serpentine grains analyzed in rocks collected along the profile $a-b$; a single grain gave $1.2 \mathrm{wt} . \%$, raising the mean value to 0.15 wt. $\% \mathrm{Cr}_{2} \mathrm{O}_{3}$ in compositions of the "normal" grains of serpentine (Table 5). As with $\mathrm{Cr}$, the $\mathrm{Al}$ content of these grains is notably low, yielding a range $\leq 0.01$ to $0.3 \mathrm{wt} . \%$, with a mean of $0.04 \mathrm{wt} . \%$ $\mathrm{Al}_{2} \mathrm{O}_{3}$.

The anomalously $\mathrm{Cr}-\mathrm{Al}$-rich grains of serpentine, hitherto unreported, were encountered only in two samples, Pds-93 and Pds-97, which belong to the lower portion of layered series and pertain to specimens of dunite collected near the northeastern margin of the complex and in the Dunite block. In these samples, the observed extent of serpentinization of olivine is minor. The dunitic rock consists of more magnesian olivine in sample Pds-97 $\left[\mathrm{Fo}_{89.2-89.5}\right.$, with $0.37-0.39$ wt.\% $\mathrm{NiO}]$, compared with other samples analyzed in the eastern segment of the $a-b$ traverse.

The compositional datasets obtained via WDS point-analyses in different areas of these veinlets (Fig. 10) are internally consistent; these are invariably enriched in $\mathrm{Cr}$ (up to $2.5 \mathrm{wt} . \% \mathrm{Cr}_{2} \mathrm{O}_{3}$ ) and $\mathrm{Al}$ ( 4.0 wt. $\% \mathrm{Al}_{2} \mathrm{O}_{3}$ ); these elements show a homogeneous distribution and narrow ranges of variations in values $(\mathrm{Cr}+\mathrm{Al})$ (Table 6). The close association of elevated levels of $\mathrm{Cr}$ and $\mathrm{Al}$ contrasts with the $\mathrm{Cr}-\mathrm{Al}$-poor compositions of most of the grains of "normal" serpentine analyzed at PadosTundra. Interestingly, compositions of the $\mathrm{Cr}-\mathrm{Al}$ rich serpentine in Pds-97 exhibit slightly higher values of their $M g \#$ (95.3-95.7) than those in Pds-93 (94.0-94.9). This characteristic reflects the more magnesian character of environment inferred for sample Pds-97, established on the basis of compositions of the associated minerals.

The chromian serpentine occurs as fracturefilling material; indeed, there is no evidence for a fiber development perpendicular to the walls of fractures (Fig. 10). This mode of occurrence is presumably not pseudomorphic after olivine (F.J. Wicks, pers. commun. to R.F.M.). In addition, a pseudomorphic serpentine growing at the expense of olivine, depleted as it is in $\mathrm{Cr}$ and $\mathrm{Al}$, could not contain much $\mathrm{Cr}$ at all, and certainly not that much Al. In general, $\mathrm{Cr}$ is fairly immobile, or its mobility is rather limited in natural systems, at least in relatively reducing environments. We thus presume that 
Table 5. Chromium contents of rock-forming silicates, hydrous silicates and carbonate minerals in the Pados-Tundra complex, Kola Peninsula.

\begin{tabular}{lcccc}
\hline & Mineral & $\begin{array}{c}\text { Ranges } \\
\left(\mathrm{Cr}_{2} \mathrm{O}_{3} \text { in wt.\%) }\right.\end{array}$ & Mean (wt.\%) & $\begin{array}{c}\text { Number of grains } \\
\text { analyzed }\end{array}$ \\
\hline 1 & $\leq 0.04-0.22$ & $\leq 0.04$ & 46 \\
2 & Fo-rich olivine & $\leq 0.04-1.08$ & 0.56 & 67 \\
3 & En-rich orthopyroxene & $\leq 0.04-0.35$ & 0.13 & 31 \\
4 & Tremolite & $\leq 0.04-0.17$ & 0.05 & 17 \\
5 & Anthophyllite & $0.92-3.71$ & 2.68 & 61 \\
6 & Clinochlore & $\leq 0.04-0.86$ & 0.10 & 103 \\
7 & Talc & $\leq 0.04-1.18$ & 0.15 & 14 \\
8 & Serpentine & $\leq 0.04-0.39$ & 0.07 & 8 \\
9 & Magnesite & $\leq 0.04-0.11$ & 0.06 & 18 \\
\hline
\end{tabular}

Note. These results of WDS analyses were acquired using a JEOL JXA-8200 electron microprobe.

$\mathrm{Cr}$ and $\mathrm{Al}$ were locally enriched in the deuteric fluid from which the $\mathrm{Cr}-\mathrm{Al}$-rich serpentine crystallized. This suggestion is consistent with findings of Mitchell \& Putnis (1988), who inferred the crystallization of serpentine in kimberlite voids from a residual $\mathrm{MgO}-\mathrm{SiO}_{2}-\mathrm{H}_{2} \mathrm{O}$-rich fluid at 600 to $400{ }^{\circ} \mathrm{C}$. In our case, because of the presence of high amounts of $\mathrm{Cr}^{3+}$ and $\mathrm{Al}^{3+}$, the temperature of crystallization of the $\mathrm{Cr}-\mathrm{Al}$-rich serpentine could exceed the upper limit $\left(600{ }^{\circ} \mathrm{C}\right)$ inferred for the "normal" serpentine. Caruso \& Chernosky (1979) showed that stabilities of lizardite and antigorite are compositionally dependent; the thermal stability of lizardite is substantially increased by the incorporation of $\mathrm{Al}$ in solid solution. The experimental data of Padrón-Navarta et al. (2010) are internally consistent on this point; results obtained for Al-Cr-rich antigorite (3.7 wt.\% $\mathrm{Al}_{2} \mathrm{O}_{3}$ and 0.59 wt. $\% \mathrm{Cr}_{2} \mathrm{O}_{3}$ ) indicate that the $\mathrm{Al}-$ $\mathrm{Cr}$ enrichment leads to an expansion of the field of serpentine stability by $60-70{ }^{\circ} \mathrm{C}$ (at $1.8 \mathrm{GPa}$ ) beyond the antigorite stability calculated in the Al-Cr-free system. These experiments imply that our serpentine-type phase, strongly enriched in $(\mathrm{Cr}+\mathrm{Al})$, could well have formed close to $650^{\circ} \mathrm{C}$. Such a temperature is beyond the field of stability of lizardite. In contrast, Andreani et al. (2008) proposed that low-temperature conditions would likely favor segregation of trivalent cations and their incorporation in the sheet structure during crystallization of polyhedral serpentine.

We thus suggest that the serpentine is likely antigorite formed by the rapid supersaturation of the deuteric fluid, as there is no evidence of active replacement of the olivine perpendicular to the walls of fractures (Fig. 10). In antigorite, $\mathrm{Al}$ is assumed to have been incorporated through a coupled mechanism of substitution $\left[2 \mathrm{Al}^{3+} \leftrightarrow\right.$ $\mathrm{Mg}^{2+}+\mathrm{Si}^{4+}$ ] (i.e., the Tschermaks exchange; e.g., Caruso \& Chernosky, 1979; Padrón-Navarta et al., 2010). In our case, the mean values based on the 15 WDS point-analyses of the $\mathrm{Al}-\mathrm{Cr}$-rich serpentine (Table 6) are: $1.93 \mathrm{Si}$ (max. 1.95), $0.20 \mathrm{Al}_{\text {tot. }}$, and $0.07 \mathrm{Cr}$ a.p.f.u. The Si site thus is largely occupied by $\mathrm{Si}$ atoms, and, consequently, can accommodate $-1 / 4$ to $1 / 3$ of the total content of $\mathrm{Al}^{3+}$. Therefore, the likely scheme of substitution in the Cr-Al-rich serpentine at Pados-Tundra is $\left[2\left({ }^{[6]} \mathrm{Al}+\mathrm{Cr}\right)^{3+}+\square \leftrightarrow\right.$ $\left.3 \mathrm{Mg}\left(\mathrm{Fe}^{2+}\right)\right]$; the proposed presence of vacancies $(\square)$ is consistent with the deficit inferred at octahedral sites (Table 6). This mechanism is associated with exchange of subordinate importance at tetrahedral sites: $\left[{ }^{[4]} \mathrm{Al} \leftrightarrow \mathrm{Si}\right]$. 
Table 6. Compositions of chromiferous serpentine from the Pados-Tundra complex, Kola Peninsula

\begin{tabular}{lcccccccccccc}
\hline & $\mathrm{SiO}_{2}$ & $\mathrm{TiO}_{2}$ & $\mathrm{Al}_{2} \mathrm{O}_{3}$ & $\mathrm{Cr}_{2} \mathrm{O}_{3}$ & $\mathrm{FeO}$ & $\mathrm{MnO}$ & $\mathrm{MgO}$ & $\mathrm{NiO}$ & $\mathrm{CaO}$ & $\mathrm{Na}_{2} \mathrm{O}$ & $\mathrm{K}_{2} \mathrm{O}$ & $\mathrm{Total}^{2}$ \\
\hline & $\mathrm{wt} \%$ & & & & & & & & & & & \\
1 & 42.81 & 0.04 & 3.88 & 2.19 & 3.16 & 0.02 & 37.47 & 0.16 & $\leq 0.01$ & $\leq 0.02$ & 0.01 & 89.75 \\
2 & 41.87 & 0.04 & 3.66 & 2.34 & 3.28 & 0.02 & 37.81 & 0.19 & 0.02 & $\leq 0.02$ & $\leq 0.01$ & 89.23 \\
3 & 42.35 & $\leq 0.02$ & 3.69 & 2.38 & 3.28 & 0.03 & 37.73 & 0.18 & 0.01 & $\leq 0.02$ & $\leq 0.01$ & 89.67 \\
4 & 42.50 & $\leq 0.02$ & 3.42 & 1.86 & 3.32 & 0.03 & 37.82 & 0.18 & 0.01 & 0.03 & $\leq 0.01$ & 89.17 \\
5 & 41.39 & $\leq 0.02$ & 3.91 & 2.52 & 3.33 & 0.03 & 37.92 & 0.20 & $\leq 0.01$ & $\leq 0.02$ & 0.01 & 89.29 \\
6 & 41.20 & 0.02 & 3.99 & 2.21 & 3.06 & 0.01 & 37.98 & 0.16 & 0.02 & 0.06 & 0.01 & 88.74 \\
7 & 41.57 & $\leq 0.02$ & 3.87 & 1.87 & 3.08 & 0.02 & 37.69 & 0.20 & 0.01 & $\leq 0.02$ & 0.01 & 88.32 \\
8 & 41.85 & $\leq 0.02$ & 3.64 & 2.18 & 3.29 & 0.03 & 38.65 & 0.17 & $\leq 0.01$ & $\leq 0.02$ & 0.01 & 89.82 \\
9 & 41.58 & 0.02 & 3.64 & 1.65 & 4.05 & 0.03 & 37.11 & 0.19 & 0.02 & $\leq 0.02$ & 0.01 & 88.29 \\
10 & 40.85 & $\leq 0.02$ & 3.66 & 1.73 & 4.23 & 0.03 & 37.40 & 0.19 & 0.04 & 0.01 & $\leq 0.01$ & 88.16 \\
11 & 41.35 & $\leq 0.02$ & 3.58 & 1.50 & 4.25 & 0.06 & 37.36 & 0.18 & 0.03 & 0.02 & $\leq 0.01$ & 88.34 \\
12 & 42.07 & $\leq 0.02$ & 3.51 & 1.19 & 3.85 & 0.04 & 37.91 & 0.18 & 0.04 & $\leq 0.02$ & $\leq 0.01$ & 88.80 \\
13 & 41.60 & $\leq 0.02$ & 3.76 & 2.00 & 3.79 & 0.03 & 38.13 & 0.19 & 0.04 & $\leq 0.02$ & $\leq 0.01$ & 89.58 \\
14 & 41.60 & $\leq 0.02$ & 3.60 & 1.81 & 3.57 & 0.01 & 37.45 & 0.17 & 0.06 & 0.02 & 0.01 & 88.32 \\
15 & 40.87 & $\leq 0.02$ & 3.69 & 1.61 & 3.53 & 0.04 & 37.02 & 0.21 & 0.06 & $\leq 0.02$ & $\leq 0.01$ & 87.02
\end{tabular}

Atoms performula unit ( $\mathrm{O}=7$ a.p.f.u.)

\begin{tabular}{|c|c|c|c|c|c|c|c|c|c|c|c|c|c|c|}
\hline & $\mathrm{Si}$ & $\mathrm{Ti}$ & ${ }^{[4]} \mathrm{Al}$ & ${ }^{[6]} \mathrm{Al}$ & $\mathrm{Al}_{\text {tot }}$ & $\mathrm{Cr}$ & $\mathrm{Mg}$ & $\mathrm{Fe}$ & $\mathrm{Ni}$ & $\mathrm{Mn}$ & $\mathrm{Na}$ & $\Sigma_{\text {oct. }}$ & $\Sigma_{\text {cat. }}$ & Mg\# \\
\hline 1 & 1.95 & 0.001 & 0.05 & 0.16 & 0.21 & 0.08 & 2.54 & 0.12 & 0.006 & 0.001 & & 2.91 & 4.91 & 95.5 \\
\hline 2 & 1.92 & 0.001 & 0.08 & 0.12 & 0.20 & 0.08 & 2.59 & 0.13 & 0.007 & 0.001 & & 2.93 & 4.93 & 95.4 \\
\hline 3 & 1.93 & & 0.07 & 0.13 & 0.20 & 0.09 & 2.57 & 0.13 & 0.007 & 0.001 & & 2.93 & 4.93 & 95.4 \\
\hline 4 & 1.95 & & 0.05 & 0.13 & 0.18 & 0.07 & 2.59 & 0.13 & 0.007 & 0.001 & 0.003 & 2.93 & 4.93 & 95.3 \\
\hline 5 & 1.90 & & 0.10 & 0.12 & 0.21 & 0.09 & 2.60 & 0.13 & 0.007 & 0.001 & & 2.95 & 4.95 & 95.3 \\
\hline 6 & 1.90 & 0.001 & 0.10 & 0.12 & 0.22 & 0.08 & 2.62 & 0.12 & 0.006 & 0.001 & 0.005 & 2.95 & 4.95 & 95.7 \\
\hline 7 & 1.93 & & 0.07 & 0.14 & 0.21 & 0.07 & 2.60 & 0.12 & 0.007 & 0.001 & & 2.94 & 4.94 & 95.6 \\
\hline 8 & 1.91 & & 0.09 & 0.11 & 0.20 & 0.08 & 2.63 & 0.13 & 0.006 & 0.001 & & 2.96 & 4.96 & 95.4 \\
\hline 9 & 1.93 & 0.001 & 0.07 & 0.13 & 0.20 & 0.06 & 2.57 & 0.16 & 0.007 & 0.001 & & 2.93 & 4.93 & 94.2 \\
\hline 10 & 1.91 & & 0.09 & 0.11 & 0.20 & 0.06 & 2.61 & 0.17 & 0.007 & 0.001 & 0.001 & 2.96 & 4.96 & 94.0 \\
\hline 11 & 1.93 & & 0.07 & 0.12 & 0.20 & 0.06 & 2.59 & 0.17 & 0.007 & 0.002 & 0.001 & 2.95 & 4.95 & 94.0 \\
\hline 12 & 1.94 & & 0.06 & 0.13 & 0.19 & 0.04 & 2.61 & 0.15 & 0.007 & 0.002 & & 2.94 & 4.94 & 94.6 \\
\hline 13 & 1.91 & & 0.09 & 0.11 & 0.20 & 0.07 & 2.61 & 0.15 & 0.007 & 0.001 & & 2.95 & 4.95 & 94.7 \\
\hline 14 & 1.93 & & 0.07 & 0.13 & 0.20 & 0.07 & 2.59 & 0.14 & 0.006 & 0 & 0.002 & 2.94 & 4.94 & 94.9 \\
\hline 15 & 1.93 & & 0.07 & 0.13 & 0.21 & 0.06 & 2.60 & 0.14 & 0.008 & 0.001 & & 2.94 & 4.94 & 94.9 \\
\hline
\end{tabular}

Note. Numbers 1-8 and 9-15 pertain to sample Pds-97 and Pds-93, respectively. $\mathrm{V}$ is not detected; Ca and $\mathrm{K}$ are $\leq 0.001$ a.p.f.u. each. These results were acquired at the Sobolev Institute of Geology and Mineralogy, Novosibirsk, Russia, in wavelength-dispersion spectrometry mode (WDS) using a JEOL JXA-8200 electron microprobe operated at $20 \mathrm{kV}$ and $50 \mathrm{nA}$. A finely focused beam (ca. $1 \mu \mathrm{m}$ ) was applied. As vanadium was also sought, the $\mathrm{CrK} \beta_{1} \mathrm{X}$-ray line was chosen for $\mathrm{Cr}$. The WDS data were acquired using a pyrope standard for $\mathrm{Mg}$ and $\mathrm{Al}$, diopside for $\mathrm{Ca}$ and $\mathrm{Si}$, albite $(\mathrm{Na})$, orthoclase $(\mathrm{K}), \mathrm{V}_{2} \mathrm{O}_{5}(\mathrm{~V}), \mathrm{NiFe}_{2} \mathrm{O}_{4}(\mathrm{Ni})$, and rutile $(\mathrm{Ti})$, using a ZAF JEOL program. The calculated values of minimum detection limit (MDL) in the analyses of serpentine and other minerals are: $0.01 \mathrm{wt} . \%$ ( $\mathrm{Al}, \mathrm{Ni}, \mathrm{V}, \mathrm{Mn}, \mathrm{K}$, and $\mathrm{Ca}$ ), 0.02 wt.\% ( $\mathrm{Na}, \mathrm{Ti})$, and $0.04 \mathrm{wt} . \%$ for $\mathrm{Cr}$. The accuracy and reproducibility of analytical procedures were tested and found to be of adequate quality (Korolyuk et al., 2009; Lavrent'ev et al., 2015). 
Figure 10. SEM image showing microfractures filled with Cr-Al-rich serpentine (Srp) hosted by olivine (OI) in the PadosTundra complex.

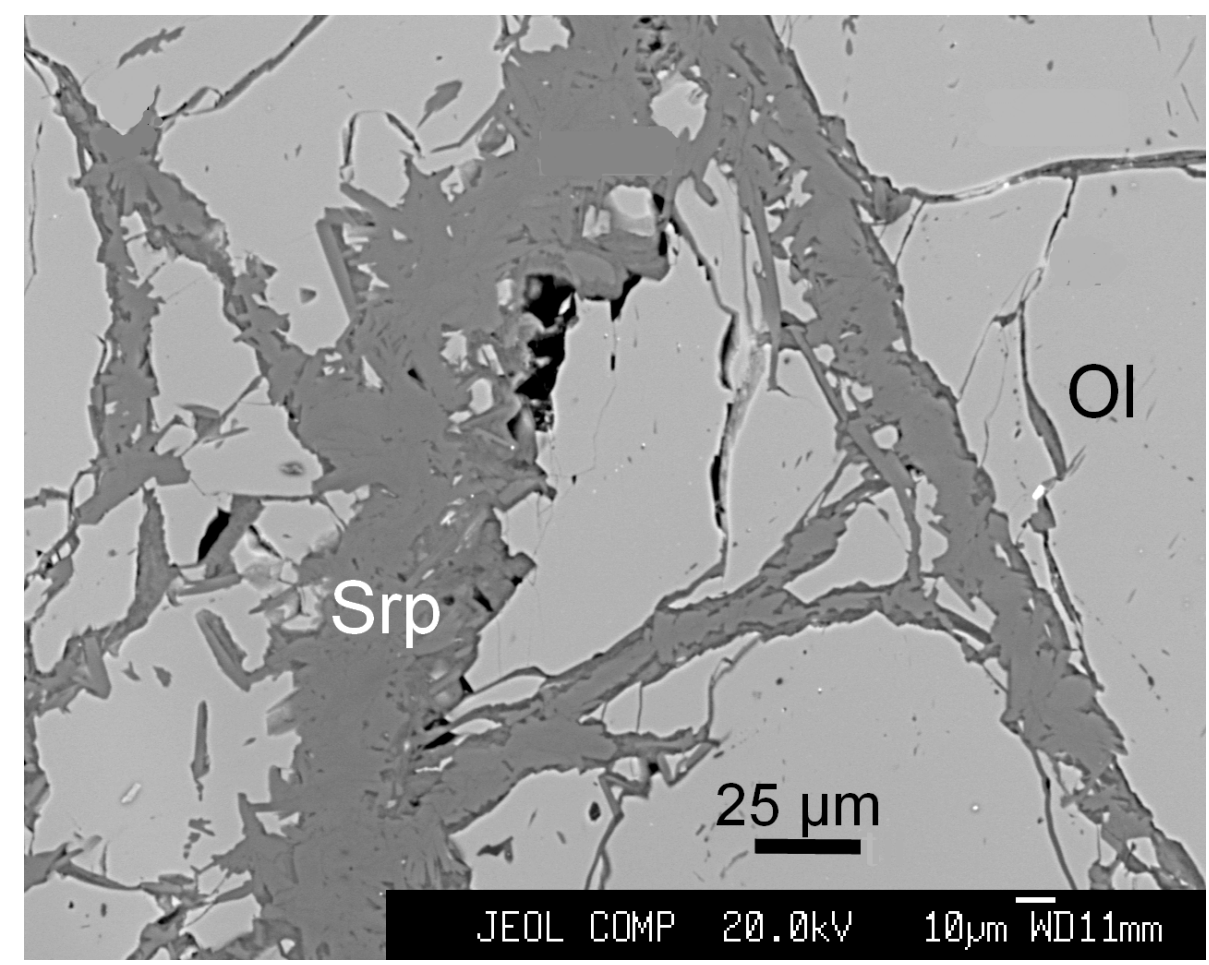

\subsection{Implications for supercooling conditions at Pados-Tundra}

On the basis of our data and observations, we further hypothesize that supercooling and metastable crystallization likely affected the melt volume in the eastern portion of the complex, in proximity of the Dunite block and relatively close to the outer contact (Fig. 2a). (1) An atypical trend of crystallization is evident for Ca-poor pyroxene, in which the observed slopes vary from relatively flatter and gradual to suddenly steep and nearly vertical in the eastern segment of the traverse $a-b$ (cf. Fig. 11d). The gradual decrease in the trend shown by En (Fig. 11d) is likely the result of normal crystallization. Presumably, cumulus olivine rich in Fo, the earliest phase to nucleate, crystallized before the supercooling conditions prevailed in the system. This suggestion explains the difference observed between the crystallization trends of orthopyroxene and olivine; the latter trend (Fig. 11a-c) exhibits only a minor extent of disturbance in contrast to that of the Ca-poor pyroxene. (2) It appears likely that oikocrystic grains of orthopyroxene, which occur as high-relief spheroids exposed in dunite near the Dunite block (Fig. 9), also are a reflection of rapid cooling in the easternmost portion of the complex. Barkov \& Lednev (1993) noted occurrences of orthopyroxene oikocrysts developed in a sill-like body of microgabbronorite that hosts a PGE-rich deposit in the Lukkulaisvaara layered intrusion, northern Karelia, Russia; there are no oikocrysts observed in "normal" members of the layered series in this intrusion. (3) The occurrence of anomalously $\mathrm{Cr}-\mathrm{Al}$-rich serpentine is consistent with metastable crystallization, likely as a consequence of localized rapid cooling proposed for the eastern part of the Pados-Tundra complex. 

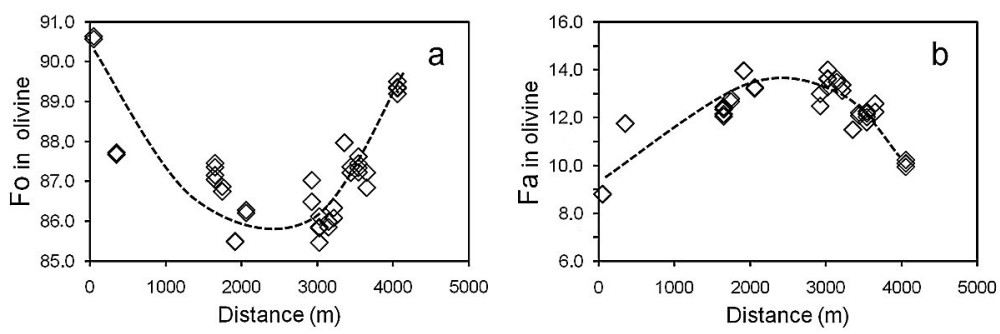

Figure 11. Compositional trends and variations in contents of $\mathrm{Fo}, \mathrm{Fa}$ (mol.\%) and $\mathrm{NiO}$ (wt.\%) in grains of olivine (a-c), along with En, Fs (mol.\%) and $\mathrm{Cr}_{2} \mathrm{O}_{3}$ (wt.\%) in orthopyroxene (d-f), documented in samples collected along the traverse $a-b$ (shown in Fig. 2a) in the Pados-Tundra complex.
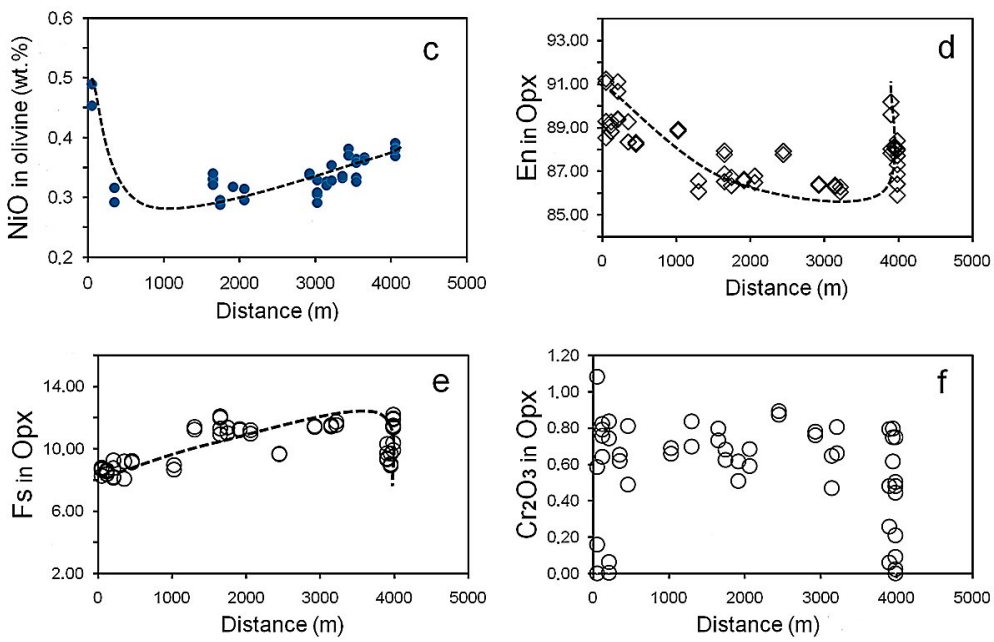

\subsection{Comparison with the Kevitsa layered intrusion, northern Finland}

The Pados-Tundra complex $(2.15 \mathrm{Ga})$ differs considerably in its age from all of the layered complexes (2.5-2.4 Ga) of the shield, closely approaching only the Kevitsa intrusion $\left(16 \mathrm{~km}^{2}\right)$ emplaced at $2.06 \mathrm{Ga}$ (Mutanen \& Huhma, 2001). These two intrusions are different in many respects. The parental magma of the Kevitsa intrusion is estimated to have been basaltic, which is consistent with olivine compositions of $\mathrm{Fo}_{77-85}$ in ultramafic rocks. Gabbroic rocks are fairly abundant there, and Ca-rich pyroxene is present in rocks of the ultramafic zone. Interestingly, komatiitic volcanic rocks of the same isotopic age $(2.06 \mathrm{Ga})$ have been found in the Kevitsa area (Mutanen \& Huhma, 2001). Grains of olivine from Ni-PGE ores at Kevitsa have compositions richest in Fo (up to $\mathrm{Fo}_{90.6}$ ). Anomalously high $\mathrm{Ni}$ contents are documented in olivine (0.51-1.78 wt.\% NiO), presumably as a result of assimilation by komatiite material (Yang et al., 2013). A possibility of such contamination by komatiite for Pados-Tundra requires further studies; also, new results of radiometric age dating could test whether or not the Pados-Tundra and Keivitsa complexes are truly synchronous $(2.1 \mathrm{Ga})$, and if they could form part of a single belt of intrusions in the northern Fennoscandian Shield.

\section{Concluding comments and continued intrigue}

The Pados-Tundra complex likely represents a large layered intrusion, as inferred on the basis of the following characteristics. (1) The complex exhibits well-recognized patterns of megacyclic and cryptic layering established in grains of olivine, Ca-poor pyroxene and chromian spinel. This intrusion presumably constitutes a single lopolith- 

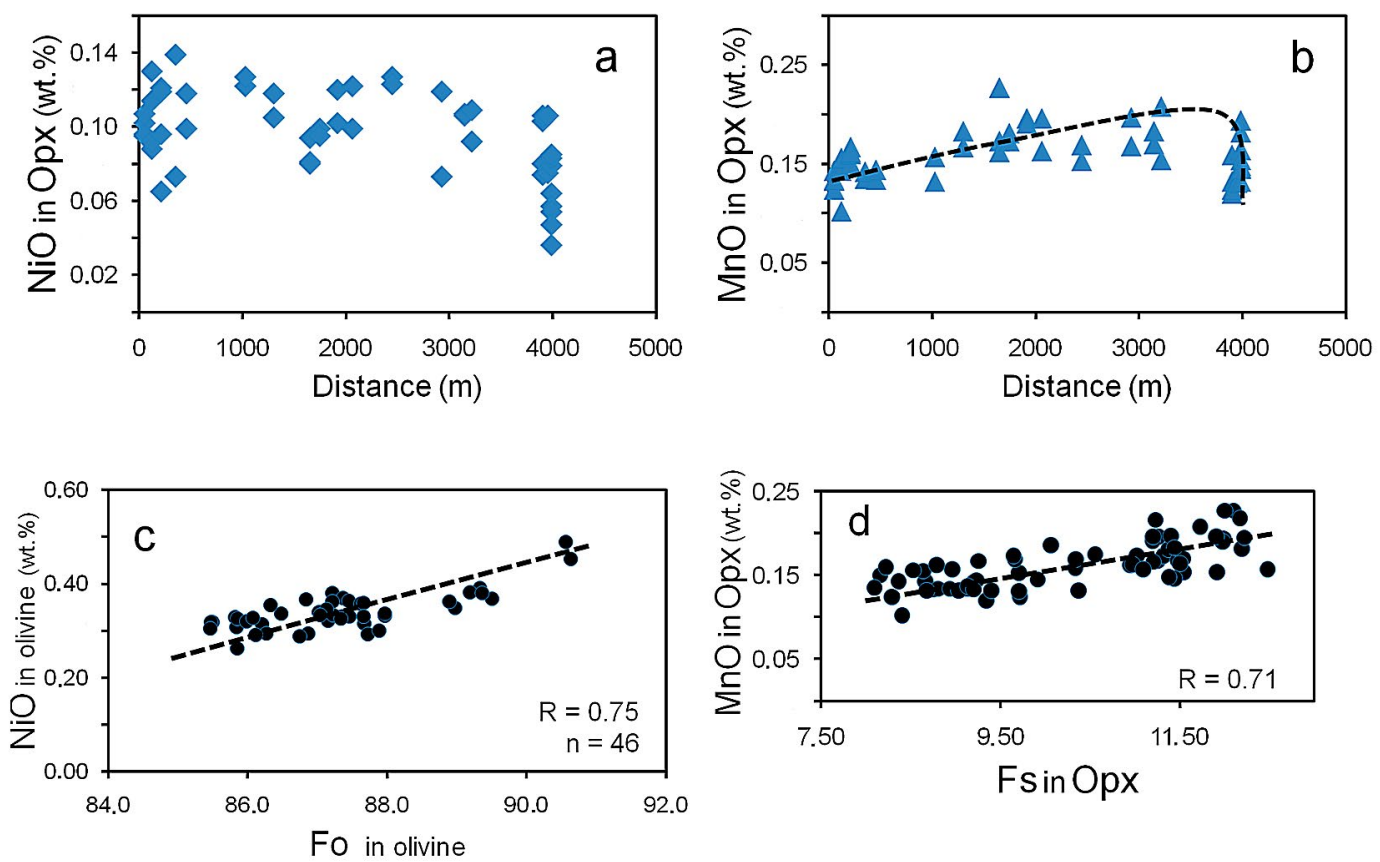

Figure 12. Variations in contents of (a) $\mathrm{NiO}$ (wt.\%) and (b) $\mathrm{MnO}$ (wt.\%) in grains of orthopyroxene observed along the traverse $a-b$ in the Pados-Tundra complex, and correlations of (c) NiO (wt.\%) vs. Fo (mol.\%) in olivine and (d) $\mathrm{MnO}$ (wt.\%) vs. Fs (mol.\%) in orthopyroxene (d).
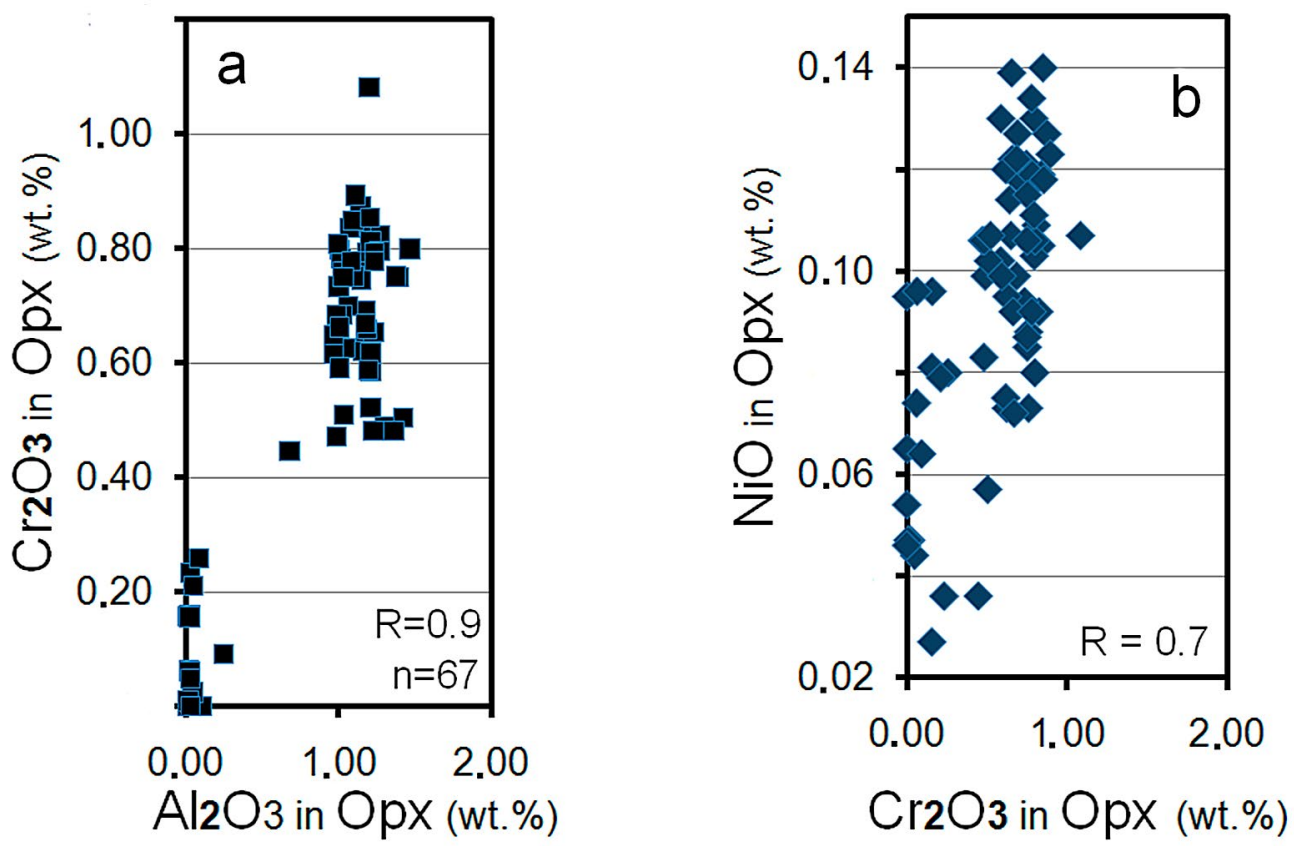

Figure 13. Plot of (a) $\mathrm{Cr}_{2} \mathrm{O}_{3}$ vs. $\mathrm{Al}_{2} \mathrm{O}_{3}$ in orthopyroxene $(n=67)$, which define a value of coefficient $(R)$ of linear regression, and (b) $\mathrm{NiO}$ vs. $\mathrm{Cr}_{2} \mathrm{O}_{3}$ in orthopyroxene. 
like body together with the Malyi Pados massif, which is likely a detached fragment of the entire complex. (2) The presence of a marginal facies is consistent with that interpretation, as is also the development of stratiform layers of chromian spinel, which is, in core phases, compositionally similar to chromite-magnesiochromite from the Paleoproterozoic layered intrusions dated at 2.4-2.5 $\mathrm{Ga}$ in the Fennoscandian Shield. (3) This line of reasoning logically leads to the proposal that preexisting mafic cumulates were removed as a result of tectonic processes and erosion. Alternatively, a fractionated melt of basic composition may have erupted continuously from the magma chamber, and, consequently, ultramafic cumulates were left behind.

On the other hand, notable differences are displayed by the Pados-Tundra complex, and by the associated bodies of the Serpentinite belt. (1) Mafic rocks are, in fact, absent in these massifs, which are dominantly composed of duniteharzburgite-orthopyroxenite successions. (2) These massifs are generally represented by lenticular or podiform bodies, which are subjected to intense dynamometamorphic stresses. Our observations indicate that ultramafic bodies at Kareka-Tundra have been tectonically introduced into the host rock (granitic gneiss or amphibolite). This mode of occurrence appears to be typical of most of other ultramafic bodies scattered along the Serpentitine belt. (3) All of these complexes are very poor in base-metal sulfides. (4) Framboidal nanophases of native ruthenium, unreported in layered intrusions, formed as a result of reactions of desulfurization and reduction of laurite at Pados-Tundra (Barkov et al., 2017). We suggest that the nature and origin of ultramafic complexes of the Serpentinite belt are still enigmatic and require further investigations.

Narrow ranges of high- $\mathrm{Mg}$ compositions are documented in olivine $\left[\mathrm{Fo}_{85.5-90.6}\right]$ and $\mathrm{Ca}$-poor pyroxene $\left[\mathrm{Wo}_{<0.1-3.0} \mathrm{En}_{85.1-91.2} \mathrm{Fs}_{8.1-12.5}\right]$ in the PadosTundra complex. Their trends of crystallization, investigated via representative cross-sections, indicate that cumulate rocks become generally more evolved toward internal portions. Therefore, comparatively primitive and early-crystallizing cumulates are exposed near the margins, which represent lower levels of the layered series. As noted, a possibility exists that earlier ultramafic rocks (olivine-orthopyroxene-chromite cumulates) remained at the present level of erosion, and upper mafic portions of the complex were completely removed by erosion or as a result of tectonic displacement.

We suggest that the internal structure of the Pados-Tundra complex differs in some aspects from what is shown on the map (Mamontov \& Dokuchaeva, 2005). The existence of a concentric arrangement, displayed by the satellite imagery, is inferred in the structure of the complex, in which earlier and primitive cumulates are exposed near the margins. These implications lead us to revise some details of the previous scheme of stratigraphy, that the stratiform-like layers of chromitite $\left(\mathrm{Cr}_{2}, \mathrm{Cr}_{3}\right.$, and $\mathrm{Cr}_{4}$; Dunite block, after Mamontov \& Dokuchaeva, 2005) occur at the uppermost level of the layered series (Fig. 4). According to our observations, the Dunite block, with its zones of chromitite and PGE mineralization, are located at a lower structural level, as might well be expected. This revision is strongly supported by the occurrence of the most strongly magnesian grains of chromian spinel $\left(M g \#\right.$ 0.6) and olivine $\left(\mathrm{Fo}_{93}\right)$ found in a chromite-rich dunite of the Dunite block (Barkov et al., 2017).

Compositions of early phases of cumulus $\mathrm{Fo}_{91}$ olivine and $\mathrm{En}_{91}$ orthopyroxene are notably magnesian in the Pados-Tundra complex. They differ from most examples reported from regional layered complexes, and closely correspond to $\mathrm{Fo}_{92}$ and $\mathrm{En}_{91.5}$ from the Great Dyke complex (Wilson, 1996). Therefore, an elevated content of $\mathrm{MgO}$ is implied in the parental melt of the Pados-Tundra complex, probably at the level close to - 14wt. $\%$ $\mathrm{MgO}$ estimated for Great Dyke (Stubbs et al., 1999).

We contend that effects of supercooling and consequent metastable crystallization may have existed in the melt in the eastern portion of the complex, in the Dunite block and relatively close to the outer contact. These conditions are likely 
reflected in the observed spheroids and ellipsoids of oikocrystic grains of orthopyroxene, which are abundant in the Dunite block. In certain cases, similar patterns of oikocrystic orthopyroxene could possibly be used as an additional criterion in searching for chromite in ultramafic units related to the Dunite block.

The perfectly shaped spheroids or ellipsoids (e.g., Fig. 9) appear to provide an indication of the postulated supercooling conditions. Indeed, a circle is the well-established solution of the isoperimetric problem. Thus, the spheroidal or elliptical shape of orthopyroxene is an expected characteristic, presumably to maximize the volume of the melt, so as to critically reduce the rate of heat loss under supercooling conditions. The formation of the phases of unique compositions, such as the Cr-Al-rich serpentine or Ru-based species of sulfoselenides (Barkov et al., 2017), could well be a reflection of metastable conditions of crystallization in the Dunite block.

\section{Acknowledgements}

We thank the referees, Drs. Petri Peltonen and Howard Naslund, and Dr. Jussi Heinonen, Editor-in-Chief, for their comments and suggestions, which were constructive and helpful. Any remaining imperfections are the authors' responsibility. A.Y.B. thanks S.S. Kramzaev, a staff member at the Cherepovets State University, for his assistance during the field investigation of the Pados-Tundra complex in the years of 2015 to 2017. We thank the staff of the analytical Lab at Sobolev Institute of Geology and Mineralogy, Siberian Branch of the Russian Academy of Sciences, Novosibirsk, Russia, for their expert assistance with the WDS EMP analyses. A.Y.B. also thanks the staff of the Federal Border Service of Russia for their permission to investigate the mounts of PadosTundra and Kareka-Tundra.

A.Y.B. gratefully acknowledges a partial support of this investigation by the Russian Foundation for Basic Research (project \# RFBR 16-05-00884).

\section{References}

Akizawa, N. \& Arai, S., 2014. Petrology of mantle diopsidite from Wadi Fizh, northern Oman ophiolite: $\mathrm{Cr}$ and REE mobility by hydrothermal solution. Island Arc 23, 312323.

https://doi.org/10.1111/iar.12074

Alapieti, T., 1982. The Koillismaa layered igneous complex, Finland - its structure, mineralogy and geochemistry, with emphasis of the distribution of chromium. Geological Survey of Finland, Bulletin 319, 116 p.

Alapieti, T., Filen, B., Lahtinen, J., Lavrov, M., Smolkin, V. \& Voitsekhovsky, S., 1990. Early Proterozoic layered intrusions in the northeastern part of the Fennoscandian Shield. Mineralogy and Petrology 42, 1-22. https://doi.org/10.1007/bf01162681

Andreani, M., Grauby, O., Baronnet, A. \& Muñoz, M., 2008. Occurrence, composition and growth of polyhedral serpentine. European Journal of Mineralogy 20, 159-171. https://doi.org/10.1127/0935-1221/2008/0020-1801

Barkov, A.Y. \& Lednev, A.I., 1993. A rhenium - molybdenum - copper sulfide from the Lukkulaisvaara layered intrusion, northern Karelia, Russia. European Journal of Mineralogy 5, 1227-1234.

https://doi.org/10.1127/ejm/5/6/1227

Barkov, A.Y. \& Martin, R.F., 2015. Anomalous Cr-rich zones in sector-zoned clinopyroxene macrocrysts in gabbro, Mont Royal, Montreal, Quebec, Canada. The Canadian Mineralogist 53, 895-910.

https://doi.org/10.3749/canmin.4357

Barkov, A.Y. \& Nikiforov, A.A., 2016. Compositional variations of apatite, fractionation trends, and a PGEbearing zone in the Kivakka layered intrusion, northern Karelia, Russia. The Canadian Mineralogist 54, 475-490. https://doi.org/10.3749/canmin.1500035

Barkov, A.Y., Nikiforov, A.A. \& Martin, R.F., 2015. A novel mechanism of spheroidal weathering: a case study from the Monchepluton layered complex, Kola Peninsula, Russia. Bulletin of the Geological Society of Finland 87, 79-85.

https://doi.org/10.17741/bgsf/87.2.003

Barkov, A.Y., Nikiforov, A.A., Halkoaho, T.A.A. \& Konnunaho, J.P., 2016. The origin of spheroidal patterns of weathering in the Pados-Tundra mafic-ultramafic complex, Kola Peninsula, Russia. Bulletin of the Geological Society of Finland 88, 105-113.

https://doi.org/10.17741/bgsf/88.2.004

Barkov, A.Y., Nikiforov, A.A., Tolstykh, N.D., Shvedov, G.I. \& Korolyuk, V.N., 2017. Compounds of Ru-Se-S, alloys of Os-Ir, framboidal Ru nanophases and laurite-clinochlore 
intergrowths in the Pados-Tundra complex, Kola Peninsula, Russia. European Journal of Mineralogy 29 (in press).

https://doi.org/10.1127/ejm/2017/0029-2666

Caruso, L.J. \& Chernosky, J.V., Jr., 1979. The stability of lizardite. The Canadian Mineralogist 17,757-769.

Daly, J.S., Balagansky, V.V., Timmerman, M.J. \& Whitehouse, M.J., 2006. The Lapland-Kola orogen: Palaeoproterozoic collision and accretion of the northern Fennoscandian lithosphere. In: Gee, D. G. \& Stephenson, R. A. (eds.), European Lithosphere Dynamics. Geological Society, London, Memoirs 32, 561-578. https://doi.org/10.1144/gsl.mem.2006.032.01.35

Dokuchaeva, V.S., 1981. The geology and ore potential of the Mount Lyavaraka massif. In "Geology of Ore Deposits in the Kola Peninsula”, Kola Science Centre, Apatity, 34-45 [in Russian].

Fyfe, W.S., 1962. On the relative stability of talc, anthophyllite, and enstatite. American Journal of Science 260, 460-466. https://doi.org/10.2475/ajs.260.6.460

Gorbachova, S.A. (principal investigator), 2000. In: "Report on prospecting works with a complex estimation of mineral resource potential in the conjunction zone of complexes of Lapland granulites and Belomorskiy gneisses in the years 1998-2000". The "Central Kola Expedition (Geological Survey)», Monchegorsk [pp. 129-134; 208209; 213-234; in Russian].

Jenkins, D.M., Ventura, G.D., Oberti, R. \& Bozhilov, K., 2013. Synthesis and characterization of amphiboles along the tremolite-glaucophane join. American Mineralogist 98, 588-600.

https://doi.org/10.2138/am.2013.4281

Korolyuk, V.N., Usova, L.V. \& Nigmatulina, E.N., 2009. On the accuracy of determining composition of principal rock-forming silicates and oxides with a JEOL JXA8100 electron microprobe. The Journal of Analytical Chemistry 64, 1042-1046. https://doi.org/10.1134/s1061934809100128

Lahtinen, R., 2012. Main geological features of Fennoscandia. Geological Survey of Finland, Special Paper 53, 13-18.

Lavrent'ev, Yu.G., Korolyuk, V.N., Usova, L.V. \& Nigmatulina, E.N., 2015. Electron probe microanalysis of rockforming minerals with a JEOL JXA-8100 electron probe microanalyzer. Russian Geology and Geophysics 56, 1428-1436 [in Russian]. https://doi.org/10.1016/j.rgg.2015.09.005

Lehtinen, M., Nurmi, P.A. \& Rämö, O.T. (eds.), 2005. Precambrian geology of Finland: key to the evolution of the Fennoscandian Shield. Elsevier, 750 pp.

Mamontov, V.P. \& Dokuchaeva, V.S., 2005. The geology and ore potential of the Pados-Tundra massif in the Kola Peninsula. Otechestvennaya Geologiya 6, 52-60 [in Russian].

Mitchell, R.H. \& Putnis, A., 1988. Polygonal serpentine in segregation-textured kimberlite. The Canadian Mineralogist 26, 991-997.
Murashov, D.F., 1958. Ultrabasic intrusions of the Serpentinite belt (Pados-Tundra etc.). In: "Geology of the USSR. Murmanskaya oblast. Geological Description” 27(1), Gosgeoltekhizdat, Moscow, 318-321 [in Russian].

Mutanen, T. \& Huhma, H., 2001. U-Pb geochronology of the Koitelainen, Akanvaara and Keivitsa layered intrusions and related rocks. Geological Survey of Finland, Special Paper 33, 229-246.

Namur, O., Abily, B., Boudreau, A.E., Blanchette, F., Bush, J.W.M., Ceuleneer, G., Charlier, B., Donaldson, C.H., Duchesne, J.-C., Higgins, M.D., Morata, D., Nielsen, T.F.D., O’Driscoll, B., Pang, K.N., Peacock, T., Spandler, C. J., Toramaru, A. \& Veksler, I.V., 2015. Igneous Layering in Basaltic Magma Chambers. In: Charlier, B. et al. (eds.), Layered Intrusions. Springer Geology, Springer Science+Business Media Dordrecht 2015, pp. 75-152. https://doi.org/10.1007/978-94-017-9652-1_2

Padrón-Navarta, J.A., Hermann, J., Garrido, C.J., López Sánchez-Vizcaíno, V. \& Gómez-Pugnaire, M.T., 2010. An experimental investigation of antigorite dehydration in natural silica-enriched serpentinite. Contributions to Mineralogy and Petrology 159, 25-42. https://doi.org/10.1007/s00410-009-0414-5

Shapkin, S. \& Bayanova, T., 2009. Geochronological Sm-Nd dating of the Cr-PGE-bearing Pados Massif (NorthWest Baltic Shield): new mineral and rock isochrons. Geophysical Research Abstracts 11, EGU2009-339-3.

Shapkin, S.S., Bayanova, T.B. \& Serov, P.A., 2008. Pados-Tundra - New Sm-Nd and U-Pb data for rocks of the massif (western part of the Kola Peninsula). In: Proceedings of the XIX Conference of young scientists in the memory of Prof. K.O. Kratz, November 24-28, 2008, Geological Institute, Kola Science Centre, Apatity [in Russian].

Stubbs, H.M., Hall, R.P., Hughes, D.J. \& Nesbitt, R.W., 1999. Evidence for a high $\mathrm{Mg}$ andesitic parental magma to the East and West satellite dykes of the Great Dyke, Zimbabwe: a comparison with the continental tholeiitic Mashonaland sills. Journal of African Earth Sciences 28, 325-336.

https://doi.org/10.1016/s0899-5362(99)00007-x

Vinogradov, L.A., 1971. The formation of ultrabasic rocks in the south-western part of the Kola Peninsula (The Notozersky ultrabasic belt). In: Problems of Magmatism of the Baltic Shield. Nauka, pp. 147-153 [in Russian].

Wilson, A.H., 1996. The Great Dyke of Zimbabwe. In: Cawthorn, R.G. (ed.), Layered intrusions. Elsevier, Amsterdam,365-402. https://doi.org/10.1016/s0167-2894(96)80013-3

Yang, S.-H., Maier, W.D., Hanski, E.J., Lappalainen, M., Santaguida, F. \& Määttä, S., 2013. Origin of ultranickeliferous olivine in the Kevitsa $\mathrm{Ni}-\mathrm{Cu}-\mathrm{PGE}$ mineralized intrusion, northern Finland. Contributions to Mineralogy and Petrology 166, 81-95. https://doi.org/10.1007/s00410-013-0866-5

Zak, S.I., 1980. The Lower Proterozoic ultrabasic formations of the Kola Peninsula. Nauka, 160 p. [in Russian]. 